\title{
Energy, exergy, exergoeconomic, and exergoenvironmental analyses and multi- objective optimization of a CPC driven solar combined cooling and power cycle with different working fluids
}

\author{
S. Zandi ${ }^{1 *}$, K. Golbaten Mofrad ${ }^{1}$, A. Moradi Faraj ${ }^{2}$, G. Salehi ${ }^{1}$ \\ 1. Department of Mechanical Engineering, Central Tehran Branch, Islamic Azad University, Tehran, Iran \\ 2. Faculty of Geodesy and Geomatics Engineering, K. N. Toosi University of Technology, Tehran, Iran \\ E-mail: Sina.zandy94@gmail.com
}

Received 2 Feb. 2021, Revised 3 March 2021, Accepted 18 March 2021

\begin{abstract}
This paper aims to provide comprehensive 4E (energy, exergy, exergoeconomic, and exergoenvironmental) and advanced exergy analyses of the Refrigeration Cycle (RC) and Heat Recovery Refrigeration Cycle (HRRC) and comparison of the performance with R744 (CO2) and R744A (N2O) working fluids. Moreover, multi-objective optimization of the systems has been considered to define the optimal conditions and the best cycle from various perspectives. In HRRC, heat recovery is used as a heat source for an organic Rankine cycle. The energy and exergy analysis results show that utilizing HRRC with both refrigerants increases the coefficient of performance (COP) and exergy efficiency. COP and exergy efficiency for HRRC-R744 have been obtained 2.82 and 30.7\%, respectively. Due to the better thermodynamic performance of HRRC, other analyses have been performed on this cycle. Exergoeconomic analysis results show that using R744A leads to an increase in the total product cost. Total product cost with R744 and R744A have been calculated by $1.56 \$ / \mathrm{h}$ and $1.96 \$ / \mathrm{h}$, respectively. Additionally, to obtain the processes' environmental impact, Life Cycle Assessment (LCA) is used. Exergoenvironmental analysis showed that using R744A increases the product environmental impact by $32 \%$. Owning to the high amount of endogenous exergy destruction rate in the compressor and ejector compared to other equipment, they have more priority for improvement. Multi-objective optimization has been performed with exergy efficiency and total product cost objective functions as well as COP and product environmental impact for both refrigerants, which indicates that HRRC-R744 has better performance economically and environmentally. In optimal condition, the value of exergy efficiency, total product cost, COP, and the product environmental impact have been accounted for by $28.51 \%, 1.44 \$ / \mathrm{h}, 2.76$, and 149.01 $\mathrm{mpts} / \mathrm{h}$, respectively.
\end{abstract}

Keywords: Combined cooling and power; solar energy; compound parabolic collector; exergy; exergoeconomic; exergoenvironmental; multi-objective optimization.

\section{Introduction}

The development of sustainable energy and its use in power, heating, and cooling generation systems is of particular importance. Nowadays, according to a lack of fossil fuel, their high price, and their destructive impacts on greenhouse gas accumulation, using the solar cycle is more important than before[1]. A solar cycle can be used as an auxiliary heat resource to preheat a boiler or as an independent resource in the cycle. The first case helps to save the boiler fuel, but in another case, by increasing the solar panel surface, it will be used instead of a boiler. Although the second case is not economically viable in the early years of cycle operation, it helps to return capital over time to the extent that it can generate a net profit. On the other hand, it decreases fossil fuel consumption and combustion damage to nature[2, 3].

The utilization of solar energy in trigeneration systems, and energy, exergy, exergoeconomic analyses as well as multi-objective optimization of these systems have received much attention in recent years. Bellos et al.[4] have investigated the thermal performance of a compound parabolic collector (CPC). In the thermal analysis, two conventional fluids include oil and water, have been studied.
The results illustrate that pressurized water is the most appropriate fluid for heat transfer because of its properties and performs better than oil. Khalid et al.[5]have checked and optimized a multigenerational system by using solar energy and biomass. The results indicate that the proposed system has a better operation in terms of exergy and exergoeconomic compared to separated production systems. Mehrpooya et al. [6] have done a thermoeconomic analysis on a new integrated system that consists of an organic Rankine cycle and parabolic trough collector. Product cost rate and exergy efficiency are selected as objective functions, and optimization of the system is done by genetic algorithm. Moharramian et al.[7]have done thermodynamic and exergoeconomic analysis of a combined photovoltaic cycle with biomass to generate electricity and hydrogen. Optimization of the system has been done to set up the compressor pressure ratio. Behzadi et al.[8] have presented electricity and cooling producing systems using solar and geothermal energy. Multi-objective optimization has been done with exergy efficiency and the product cost rate as objective functions. Boyaghchi et al.[9]have done a thermoeconomic analysis and optimization of a micro solarCCHP system with an organic Rankine cycle for winter and 
summer seasons. Five key parameters, like those that turbine inlet temperature and turbine inlet pressure, is selected as decision variables, exergy efficiency, and product cost rate functions, are chosen as objective functions. Sokhansefat et al. [10]have compared solar hot water systems with flat plate collectors (FPC) and evacuated tube collectors (ETC) in terms of thermoeconomic in cold weather. The thermal and economic analysis results indicate better operation of the ETC system compared to the FPC system. Salehi et al. [11] have compared solar-assisted absorption heat pumps using solar energy and gas combustion boiler economically. The results indicate that the $\mathrm{LiBr} / \mathrm{H}_{2} \mathrm{O}$ absorption systems have the highest exergy efficiency and gas boiler, and $\mathrm{NH}_{3} / \mathrm{H}_{2} \mathrm{O}$ absorptions systems have the lowest product unit cost rate. Sadi et al.[12] have done an exergoeconomic analysis on a hybrid solar-waste has driven power plant in order to distinguish the main irreversibility. Increasing the steam extraction ratio and decreasing turbine inlet temperature will decrease electricity costs. Wellmann et al. [13]have analyzed a cogenerating system in order to desalinate seawater and generate electricity by using solar energy in terms of exergy and exergoeconomic. Panahi et al.[14] have designed, manufactured, and experimentally studied a prototype solar water heater with a compound parabolic concentrator. Hourly and monthly analysis of water temperature variations for the developed system showed that with increasing incoming radiation to the water heater, the system's thermal efficiency decreased, with the highest efficiency being in April and the lowest in July.

In addition to considering the thermodynamic and economic aspects of energy systems, the consideration of environmental issues and combination with exergy analysis and the presentation of exergoeconomic analysis have also been studied in many recent studies. Rosato et al.[15]have dynamically simulated and analyzed a solar hybrid district heating with seasonal storage over five years in terms of energy, environmental and economic. The performance of alternative auxiliary back-up systems is estimated. Vazini Modabber et al.[16] have modified a power-water cogeneration system by combining the existing plant with solar and inlet air cooling systems and have carried out dynamic energy, exergy, exergoeconomic, and exergoenvironmental analyses (4E) analyses of the system. Absorption chillier for inlet air-cooling of a compressor and parabolic trough collector for solar heating has been incorporated with the present unit. Baghernejad et al.[17] have considered an economic and environmental optimization and analysis of a trigeneration system with solar energy. Saadon et al.[18]have analyzed a semitransparent photovoltaic/thermal system in terms of exergy, exergoeconomic, and enviroeconomic. The results indicate a lower loss rate and, consequently, better economic and environmental impacts of the proposed system compared to the opaque photovoltaic/thermal system. Caliskan[19] has done energy, exergy, environmental, enviroeconomic, exergoenvironmental, and exergoenviroeconomic analysis on a solar collector. It was shown that exergoenviroeconomic and exergoenvironmental analysis assesses the system more effectively. Montazerinejad et al. [20]have assessed a new CCHP system with solar energy regarding exergoeconomic and exergoenvironmental. The results express that the storage tank has the most exergy destruction rate and the highest cost of exergy destruction rate. Esmaeilzadehazimi et al.[21] analyzed an MHD-Magneto hydrodynamic- cycle from $4 \mathrm{E}$ points of view. In MHD cycles, the waste heat can be recovered and used in the Brayton cycle as a heat source. Bonforte et al. [22] have checked the exergoeconomic and exergoenvironmental analysis of a combined powerproducing cycle with solar energy. The environmental analysis of the system is done by using Life Cycle Assessment (LCA). Cavalcanti et al. [23] have analyzed two $\mathrm{CO}_{2}$ capture and storage and concentrated solar power systems in order to decrease the greenhouse gases from an exergoenvironmental viewpoint for a plant of the natural gas combined cycle for power production. Sanaye et al.[24] have investigated a combined cooling, heating, power, and water system from energy, exergy, exergoeconomic, and exergoenvironmental (4E) viewpoint. Multi-objective optimization of the system is performed with exergy efficiency and annual total cost objective functions. Golbaten Mofrad et al.[25] have conducted 4E analyses for a cascade refrigeration system with natural working fluids. The cycle's multi-objective optimization has been performed using the objective functions of exergy efficiency, product cost rate, energy efficiency, and product environmental impact on finding the system's optimal operating conditions. Moreover, in another study, they have compared two refrigeration and combined cooling and power cycles with R744 and R744A working fluids in terms of 4E analyses[26]. Adibhatla et al.[27]have designed a solar field consisting of parabolic trough collectors to preheat the water in a thermal power plant and evaluate its impact. 4E analysis was performed on the investigated system. Energy and exergy efficiencies, economic parameters, and environmental parameters such as reducing coal consumption and $\mathrm{CO} 2$ production were determined. Ameri et al.[28]are evaluating a new solar hybrid cycle. The new system uses the parabolic trough solar cycle in the conventional hybrid cycle. The Life Cycle Assessment for the system has been performed, and the results show that power generation at the new solar power plant has a less environmental impact. Ghaith et al.[29]have explored the use of parabolic trough collectors with a doubleeffect absorption chiller to provide the cooling load in residential areas. The economic and environmental impact assessment of the system has been carried out. Rafat et al.[30] have analyzed a small solar-driven Kalina power plant from an energy, exergy, economic and environmental perspective. The comparative analysis between the proposed solar Kalina cycle and some renewable and fossil power plants has been done in terms of energy and exergy performance. Modabber et al.[31] have evaluated a desalination unit with power and water cogeneration plant. $4 \mathrm{E}$ analysis has been carried out, and in order to exergoenvironmental analyze LCA has been utilized.

Selecting the proper working fluid for thermodynamic cycles is essential. Many researchers have considered various analyses of thermodynamic cycles with different working fluids in order to determine the best one from different aspects. Boyaghchi et al.[32] have evaluated and optimized a combined cooling, heating, and power (CCHP) cycle with solar energy from exergy, exergoeconomic, and exergoenvironmental viewpoints. Four appropriate refrigerants for the cycle have been assessed. In addition, in another research[33], they have checked another solarCCHP. Exergetic efficiency, the product cost rate, the product environmental impact are chosen as objective functions, and four different refrigerants have been compared together. Nemati et al.[34]have optimized and compared three different solar energy-driven organic flash cycles (OFC) from exergy and exergoeconomic point of 
view, and five different working fluids are considered for the cycle. Khaliq [1] has checked a combined power and cooling cycle (CCP) using an organic Rankine cycle and heliostat in terms of energy and exergy. R141b refrigerant is selected as a working fluid. Desai et al. [35] have made a

Previous studies have shown that fossil fuels, along with the limitations of energy sources and their cost due to combustion, lead to environmental pollution and greenhouse gas emissions. Working exclusively with clean fuels has a special place. They also have design complexities in determining the type of solar collector depending on the location used.

Considering the importance and advantages of power plants using renewable energy, as well as research on them, the 4E (Energy, Exergy, Exergoeconomic and exergoenvironmental) analysis of the combined cooling and power (CCP) system driven by solar energy without fossil fuels needs further investigation. Therefore, the compound parabolic collector (CPC) and five working fluids include R245fa, R236FA, R152A, R142b, and R134a with different thermodynamic properties under the same environmental conditions are selected, and 4E analysis is done. Finally, multi-objective optimization has been performed with the Genetic algorithm, and the optimized values were determined for each working fluid. By comparing the results, the most appropriate fluid was selected.

The present research's most outstanding novelty is using the compound parabolic collectors in the combined cooling and power cycle just driven by solar energy without consuming fossil fuels. Besides, comparing and multiobjective optimization of the system's performance from $4 \mathrm{E}$ viewpoints with five different organic fluids and finally selecting the best-working fluid from different aspects have been carried out. thermoeconomic comparison between two organic Rankine and steam Rankine cycles and parabolic trough collectors. R113 and isohexane are appropriate for the steam Rankine cycle in terms of thermodynamic and economical.

\section{System Description}

The selected cycle in this research has two parts. The first part is used to produce power and cooling using an organic fluid and consists of the ejector, turbine, pump, condenser, and evaporator. The second part is a solar system, which gets the sun heat by compound parabolic collectors (CPC) and transfers it to circulating water in the cycle. Transferring heat between two parts is done by heat recovery vapor generation (HRVG). The heated water in point 16 enters HRVG in order to super-heat the organic fluid in point 2 and provide the condition for better operation of the turbine. The outlet refrigerant in point 3, which has lower pressure and temperature than before, enters the ejector. With a specified decreasing pressure ratio and increasing velocity, it will decrease the condenser inlet temperature. The organic fluid with a specified mass flow ratio will be sent to the pump and the evaporator after condensing. The organic fluid in the evaporator gets the inlet water heat and makes the environment temperature low. In this research, five organic fluids: R245fa, R236FA, R152A, R142b, R134a, are used. The thermodynamic properties of each fluid are presented in Table 1[36].

The purpose of this study is to compare the system with different fluids from an energy, exergy, and exergoeconomic viewpoint. The base of designing the CCP cycle using the solar system is installing a cycle with each working fluid. A different number of solar collectors is determined to provide the needed thermal for super-heat the working fluids.

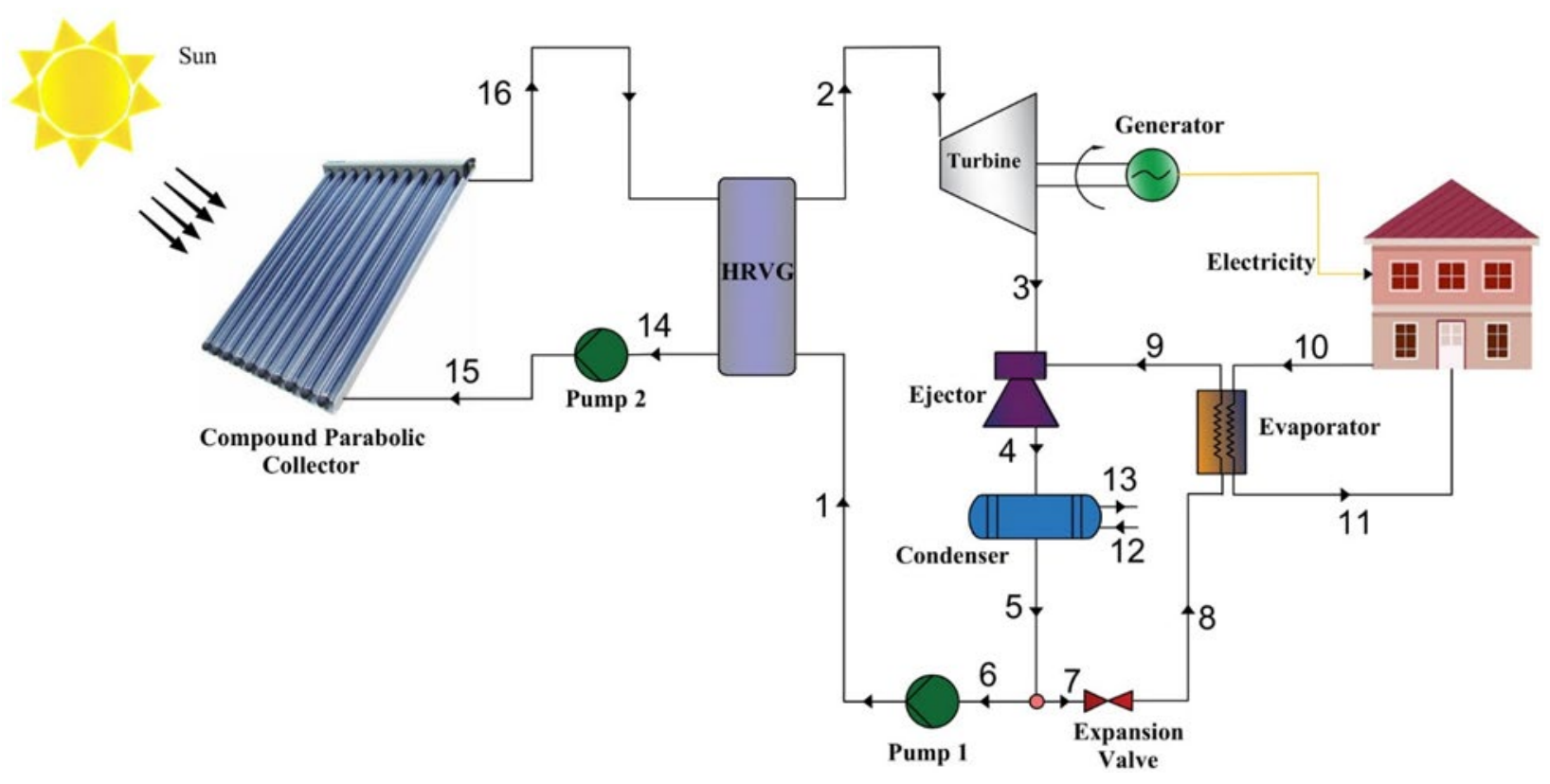

Figure 1. Schematic diagram of the CCP cycle with the solar system. 


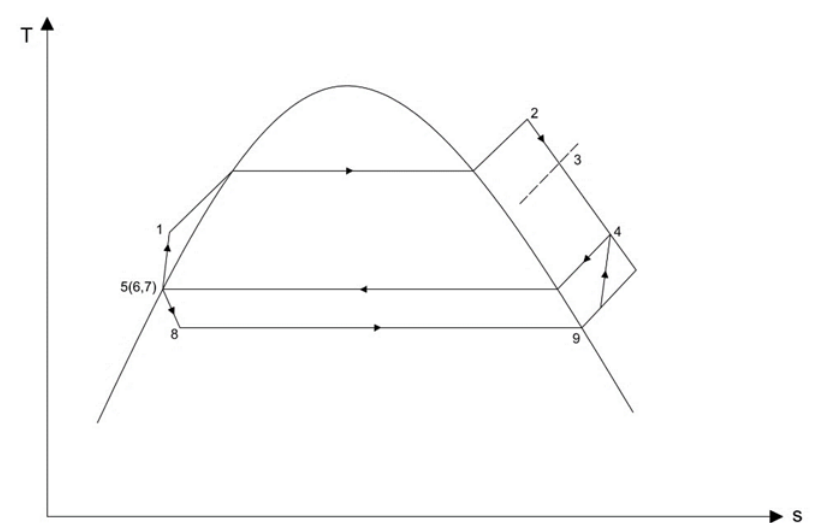

Figure 2. T-s diagram of the CCP cycle with the solar system.

Table 1. Input parameter values for analysis.

\begin{tabular}{lllll}
\hline $\begin{array}{l}\text { ASHARE } \\
\text { Code }\end{array}$ & $\begin{array}{l}\text { Critical } \\
\text { temperature } \\
(\mathrm{K})\end{array}$ & $\begin{array}{l}\text { Critical } \\
\text { pressure } \\
(\mathrm{kPa})\end{array}$ & $\begin{array}{l}\text { Type of } \\
\text { fluid }\end{array}$ & $\begin{array}{l}\text { Ozone } \\
\text { depletion } \\
\text { potential }\end{array}$ \\
\hline R245fa & 427.2 & 3640 & Dry & 0 \\
R236FA & 398.07 & 3200 & Dry & 0 \\
R152A & 386.41 & 4516.7 & Wet & 0 \\
R142b & 410.26 & 4055 & Isentropic & 0.12 \\
R134a & 345.8 & 3764 & Isentropic & 0.055 \\
\hline
\end{tabular}

\section{Thermodynamic Modeling and Assumptions}

A couple of MATLAB and REFPROP 9.1 is used for thermodynamic analysis of the CCP cycle. In this research, the solar system of compound parabolic collectors (CPC) type is selected. According to the average total radiation assumed for Yazd city, its equations are calculated and analyzed for a year. The input thermodynamic parameters with the characteristic of selected CPCs are presented in Table 2[37].

Table 2. Input parameter and characteristic of collectors for thermodynamic analysis.

\begin{tabular}{ll}
\hline Input parameters & Values \\
\hline Turbine inlet pressure (kPa) & 1200 \\
Turbine inlet temperature(K) & 388 \\
Turbine back pressure (kPa) & \\
$\mathrm{P}_{3, \mathrm{R} 152 \mathrm{~A}}$ & 610 \\
$\mathrm{P}_{3, \mathrm{R} 142 \mathrm{~b}}$ & 610 \\
$\mathrm{P}_{3, \mathrm{R} 236 \mathrm{FA}}$ & 550 \\
$\mathrm{P}_{3, \mathrm{R} 245 \mathrm{fa}}$ & 400 \\
$\mathrm{P}_{3, \mathrm{R} 134 \mathrm{a}}$ & 750 \\
HRVG effectiveness (\%) & 100 \\
Diffuser efficiency (\%) & 80 \\
Nozzle efficiency (\%) & 75 \\
Mixture efficiency (\%) & 80 \\
Turbine isentropic efficiency (\%) & 75 \\
Pump 1 isentropic efficiency (\%) & 85 \\
Pump 2 isentropic efficiency (\%) & 80 \\
Environment pressure (kPa) & 101.3 \\
Ambient temperature(K) & 298 \\
System operating Time (hour) & 2000 \\
Component lifetime (year) & 20 \\
Transmissivity of the cover glazing & 0.9 \\
Mirror reflectivity & 0.9 \\
Absorptivity of receiver & 0.87 \\
The average number of reflections & 0.6 \\
Collector heat loss coefficient $\left(\mathrm{W} / \mathrm{m}^{2} \mathrm{~K}\right)$ & 2.1 \\
Concentration ratio & 4.5 \\
\hline
\end{tabular}

\subsection{Assumptions}

Modeling the CCP cycle is done according to the first and second laws of thermodynamic. Balancing the equations is done according to the below assumptions[1]:

1. The design conditions are considered at $298 \mathrm{~K}$ and 1 bar.

2. The operation of the ejector is assumed adiabatically.

3. The index of weather cleanliness for Yazd is assumed favorable throughout the year.

4. The operation of the expansion valve is considered constant enthalpy.

5. The considered conditions for all the organic fluids except the backpressure turbine are the same.

6. The operation of the cycle is in a steady-state condition.

7. The friction of all components is neglected.

8. Isentropic efficiency is considered for the pumps and turbine.

\subsection{Energy Modeling}

Energy transfer in all the components is done by the usage of controlling volume balance equations in a steadystate, according to Eq. (1), $\dot{m}_{i}$ and $\dot{m}_{e}$ are the inlet and outlet mass flow rate, respectively [38].

$$
\dot{Q}-\dot{W}=\sum \dot{m}_{i} h_{i}+\sum \dot{m}_{e} h_{e}
$$

Different solar systems are available in the industry that, according to their efficiency, usage place, and engineers' opinion, they will be designed and utilized. Parabolic collectors can concentrate the sun's diffuse radiation when the weather is cloudy, and there is no beam radiation of the sun to increase the water temperature significantly. According to NASA research, the average total radiation for Yazd city in 2000 hours a year is considered about $850 \mathrm{~W} / \mathrm{m}^{2}$ [39]. Utilized equations for CPC are given in Table $3[37,40]$.

Table 3. Equations used in the solar collectors.

\begin{tabular}{lc}
\hline \multicolumn{1}{c}{ Parameter } & Equation \\
\hline Useful energy delivered & $Q_{u}=F_{R}\left[S\left(A_{a}\right)-A_{r} U_{L}\left(T_{n f, i}-T_{a}\right)\right]$ \\
Absorber radiation & $S=G_{t} \cdot \tau_{\text {cover } r} \tau_{C P C} \cdot \alpha_{r} \cdot \gamma$ \\
$\begin{array}{l}\text { The diffuse radiation } \\
\text { correction factor } \\
\text { The crossing factor of } \\
\text { CPC } \\
\text { Energy of CPC }\end{array}=1-\left(1-\frac{1}{C}\right) \frac{G_{D}}{G_{T}}$ \\
Exergy of CPC \\
$\tau_{C P C}=\rho^{n}$ \\
\end{tabular}

In Table $3, \mathrm{~T}_{\mathrm{CPC}}$ is the temperature of the solar receiver surface. Most studies have used solar temperature $\left(\mathrm{T}_{\text {sun }}\right)$ to calculate the exergy of the solar collectors. Nevertheless, according to the study conducted by Colakoglu and et al.[41], the use of $\mathrm{T}_{\text {sun }}$ is apparently valid only on the surface of the sun. Owing to solar collectors are located on the earth's surface (not the sun's surface), and a solar system on the earth's surface can only use solar heat flux, $\mathrm{T}_{\mathrm{CPC}}$ should be utilized. 
Solar receiver temperature is related to the collecting efficiency as Eq. (2)[41].

$$
\eta_{\text {Collector }}=1-\frac{\sigma T_{C P C}^{4}}{G_{t} C}
$$

where $\sigma$ is the Stefan-Boltzmann constant, $G_{t}$ is the solar heat flux on the $\mathrm{CPC}$ surface, $\mathrm{C}$ is the concentration ratio of solar collector, and $\eta_{\text {Collector }}$ is the collector efficiency, which is defined according to design conditions (in the present study is assumed 0.55)[41].

The absorbed heat of the environment by the evaporator is calculated according to Eq. (3)[42].

$$
\dot{Q}_{\text {Evaporator }}=\dot{m}_{8}\left(h_{9}-h_{8}\right)
$$

The ejector is divided into three parts: nozzle, mixing chamber, and diffuser. The flow is assumed to the steadystate and adiabatic. The schematic of the ejector is illustrated in Figure 3.

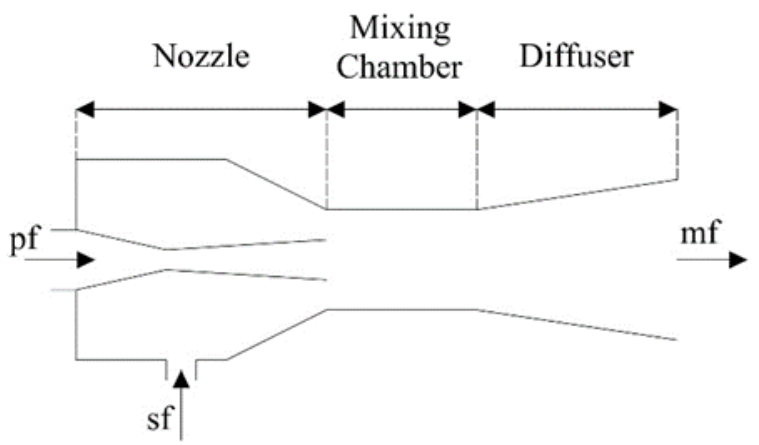

Figure 3. The schematic of different parts of the ejector.

The modeling of ejector has been conducted based on the conservation of mass, momentum, and energy equations. The equations utilized for modeling are presented in Table 4[43].

According to the turbine's outlet power and the absorbed heat by the evaporator, energy efficiency is calculated by Eq. (4)[42].

$$
\eta_{\text {Energy, CCP }}=\frac{\dot{W}_{\text {Turbine }}-\dot{W}_{\text {Pump }, 1}-\dot{W}_{\text {Pump }, 2}+\dot{Q}_{\text {Evaporator }}}{\dot{Q}_{\text {Solar }}}
$$

\subsection{Exergy Modeling}

The system's total exergy is divided into physical exergy and chemical exergy calculated by Eq. (5)[44].

$$
\dot{E} X_{\text {Total }}=\dot{E} X_{P h}+\dot{E} X_{C h}
$$

Since there is no chemical process in the CCP cycle, the chemical exergy is not considered. The exergy balance equation is determined as Eq. (6), regarding the rate of fuel exergy $\left(\dot{E} X_{F, k}\right)$ and product exergy $\left(\dot{E} X_{P, k}\right)[42]$.

$$
\dot{E} X_{F, k}=\dot{E} X_{P, k}+\dot{E} X_{D, k}+\dot{E} X_{L, k}
$$

The physical exergy rate is given in Eq. (7). In addition, the exergy destruction ratio and the exergy efficiency of equipment are presented in Eq. (8) and Eq. (9), respectively[44].

$$
\begin{aligned}
\dot{E} X_{p h} & =\dot{m}\left[\left(h-h_{0}\right)-T_{0}\left(s-s_{0}\right)\right] \\
Y_{D, K} & =\frac{\dot{E} X_{D, K}}{\dot{E} X_{D, \text { total }}} \\
\eta_{E X, k} & =\frac{\dot{E} X_{P, k}}{\dot{E} X_{F, k}}
\end{aligned}
$$

The exergy efficiency of the CCP cycle is presented in Eq. (10) pursuant to the rates of fuel exergy and product exergy[45].

$$
\eta_{E X, C C P}=\frac{\dot{E} X_{P, \text { total }, C C P}}{\dot{E} X_{F, \text { total }, C C P}}=\frac{\dot{E} X_{P, \text { Evaporator }}+\dot{E} X_{P, \text { Turbine }}}{\dot{E} X_{\text {Solar }}}
$$

The exergy equations of fuel, product, and destruction for all components are presented in Table 5.

\subsection{Exergoeconomic Modeling}

The most significant aim of exergoeconomic analysis is to define the different costs of fuel exergy and product exergy. Therefore, the cost rates should be determined by exergy in Eq. (11)[44].

$$
\dot{C}_{k}=c_{k}\left(\dot{E} X_{k}\right)
$$

The balance of cost equations is represented as Eq. (12), conforming to the inlet and outlet flow of components and their purchase cost rates[44].

$$
\sum \dot{C}_{e}+\dot{C}_{w}=\dot{C}_{Q}+\sum \dot{C}_{i}+\dot{Z}
$$

Pursuant to the balance of exergoeconomic equations, the product cost rate consists of fuel cost rate and investment cost, as is shown in Eq. (13) and destruction cost rate calculated by Eq. (14)[44].

$$
\begin{aligned}
& \dot{C}_{P, k}=\dot{C}_{F, k}+\dot{Z}_{k} \\
& \dot{C}_{D, k}=c_{P}\left(\dot{E} X_{D}\right)
\end{aligned}
$$

The investment costs rate of all components are given in Eqs. 15 to 22. The investment cost of equipment is defined according to their size.

HRVG:[46]

$Z_{H R V G}^{C l}=130\left(\frac{A_{H R V G}}{0.093}\right)^{0.78}$

Pump:[47]

$Z_{\text {Pump }}^{C L}=3450\left(\dot{W}_{\text {Pump }}\right)^{0.71}$

Turbine:[46]

$Z_{\text {Turbine }}^{C L}=4405\left(W_{\text {Turbine }}\right)^{0.7}$

Expansion valve:[48]

$Z_{\text {Expansion valve }}^{C L}=114.5\left(m_{i}\right)$ 


\begin{tabular}{|c|c|}
\hline Parameter & Equation \\
\hline Entrainment ratio & $\mu=\frac{\dot{m}_{s f}}{\dot{m}_{p f}}$ \\
\hline Nozzle efficiency & $\eta_{n}=\frac{h_{p f, i n}-h_{p f e r i}}{h_{p f i n}-h_{p f i s}}$ \\
\hline Primary flow outlet velocity & $u_{p f, e x i}=\sqrt{2 \eta_{n}\left(h_{p f, i n}-h_{p f, i i}\right)}$ \\
\hline The mixing chamber momentum conservation & $\dot{m}_{p f} u_{p f e x i}+\dot{m}_{s f} u_{\text {sferi }}=\left(\dot{m}_{s f}+\dot{m}_{p f}\right) u_{m f f i s}$ \\
\hline Secondary flow outlet velocity & $u_{s f, i n}=\sqrt{2 \times\left(h_{s f, i n}-h_{s f, e x i}\right)}$ \\
\hline The velocity of mixed flow & $u_{m f, i s}=\frac{u_{p f e x i}}{1+\mu}$ \\
\hline Mixing efficiency & $\eta_{m}=\frac{u_{m f}^{2}}{u_{m, f i s}^{2}}$ \\
\hline The averaged velocity of mixed flow & $u_{m f}=\frac{u_{p f, e x i} \sqrt{\eta_{m}}}{1+\mu}$ \\
\hline Energy conversion in mixing chamber & $\dot{m}_{p f}\left(h_{p f f e r i}+\frac{u_{p f e x i}^{2}}{2}\right)+\dot{m}_{s f}\left(h_{s f f e x i}+\frac{u_{s f e x i}^{2}}{2}\right)=\left(\dot{m}_{s f}+\dot{m}_{p f}\right)\left(h_{m f}+\frac{u_{m f}^{2}}{2}\right)$ \\
\hline Mixed flow enthalpy & $h_{m f}=\frac{h_{p f f i n}+\mu h_{s f e x i}}{1+\mu}-\frac{u_{m f}^{2}}{2}$ \\
\hline The actual enthalpy of mixed flow outlet & $h_{m f, e x i}=h_{m f}+\frac{h_{m f, e x i, i s}+h_{m f}}{\eta_{d}}$ \\
\hline Ejector performance & $\mu=\sqrt{\eta_{n} \eta_{m} \eta_{d}\left(h_{p f, i n}-h_{p f, i s}\right) /\left(h_{m f, e x ; i s}-h_{m f}\right)}-1$ \\
\hline
\end{tabular}

Table 5. The Exergy balance of equipment.

\begin{tabular}{|c|c|c|c|}
\hline Component & Fuel exergy & Product exergy & Destruction exergy \\
\hline $\mathrm{CPC}$ & $\dot{E} X_{\text {Solar }}$ & $\dot{E} X_{16}-\dot{E} X_{15}$ & $\dot{E} X_{F, C P C}-\dot{E} X_{P, C P C}$ \\
\hline Ejector & $\dot{E} X_{3}+\dot{E} X_{9}$ & $E X_{4}$ & $\dot{E} X_{F, \text { Ejector }}-\dot{E} X_{P, \text { Ejector }}$ \\
\hline Expansion valve & $\dot{E} X_{7}$ & $\dot{E} X_{8}$ & 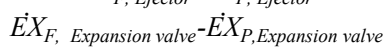 \\
\hline Evaporator & $\dot{E} X_{8}-\dot{E} X_{9}$ & $\dot{E} X_{11}-\dot{E} X_{10}$ & $E X_{F, \text { Evaporator }}-E X_{P, \text { Evaporator }}$ \\
\hline Pump 1 & $\dot{W}_{\text {Pump }, 1}$ & $\dot{E} X_{1}-\dot{E} X_{6}$ & $E X_{F, \text { Pump }, 1}-\dot{E} X_{P, P \text { ump }, 1}$ \\
\hline Pump 2 & $\dot{W}_{\text {Pump }, 2}$ & $\dot{E} X_{15}-\dot{E} X_{14}$ & $\dot{E} X_{F, \text { Pump }, 2}-\dot{E} X_{P, P \text { ump }, 2}$ \\
\hline Turbine & $\dot{E} X_{2}-\dot{E} X_{3}$ & $\dot{W}_{\text {Turbine }}$ & $\dot{E} X_{F, \text { Turbine }}-\dot{E} X_{P, \text { Turbine }}$ \\
\hline Condenser & $\dot{E} X_{4}-\dot{E} X_{5}$ & $\dot{E} X_{13}-E X_{12}$ & $\dot{E} X_{F, \text { Condenser }}-\dot{E} X_{P, \text { Condenser }}$ \\
\hline HRVG & $\dot{E} X_{16}-\dot{E} X_{14}$ & $\dot{E} X_{2}-\dot{E} X_{1}$ & $\dot{E} X_{F, H R V G}-\dot{E} X_{P, H R V G}$ \\
\hline
\end{tabular}

Condenser:[49]

$Z_{\text {Condenser }}^{C l}=8000\left(\frac{A_{\text {Condenser }}}{100}\right)^{0.6}$

\section{Evaporator:[50]}

$Z_{\text {Evaporator }}^{\text {Cl }}=309.15\left(A_{\text {Evaporator }}\right)+213.9$

Ejector:[50]

$Z_{\text {Ejector }}^{C l}=750\left(\dot{m}_{1}\right)\left(P_{4}^{0.75}\right)\left(\frac{T_{3}}{P_{3}}\right)^{0.05}$

$\mathrm{CPC}:[51]$

$Z_{C P C}^{C L}=250\left(A_{C P C}\right)$

A capital recovery factor is the ratio of a fixed annuity to the present value of receiving that annuity for a given length using an interest rate $\mathrm{I}$, the capital recovery factor is defined as Here, $\mathrm{i}$ is the interest rate (assumed to be $15 \%$ ) and $\mathrm{n}$ is the system life (considered to be 20 years) $[44,52]$.

$$
C R F=\frac{i(1+i)^{n}}{(1+i)^{n}-1}
$$

$$
\dot{Z}_{k}=\frac{Z_{k}^{C l} \cdot C R F \cdot \varphi}{t}
$$

By calculating the investment cost rate for each of the equipment used in the CCP cycle, the cost balance is according to Table 6 . In order to calculate the cost rate of each flow point, auxiliary equations are represented in this table.

Relative cost deference determines the medium partial cost rises in each exergy unit between the exergy of components' fuel and product. This parameter demonstrates the component which has the highest product cost. In order to determine this parameter, Eq. (25) is given[44].

$$
r_{c}=\frac{c_{P, k}-c_{F, k}}{c_{F, k}}
$$

One of the most substantial purposes of exergoeconomic analysis is to reduce the product cost rate. In order to achieve this aim, the exergoeconomic factor is presented. This factor for each component is determined by Eq. (26)[44].

$$
f_{c}=\frac{\dot{Z}_{k}}{\dot{Z}_{k+} \dot{C}_{D, k}+\dot{C}_{L, k}}
$$




\begin{tabular}{|c|c|c|}
\hline Component & Exergoeconomic balance & Auxiliary equations \\
\hline Turbine & $\dot{Z}_{\text {Turbine }}+\dot{C}_{2}=\dot{C}_{3}+\dot{C}_{w, \text { Turbine }}$ & - \\
\hline HRVG & $\dot{Z}_{H R V G}+\dot{C}_{1}+\dot{C}_{16}=\dot{C}_{14}+\dot{C}_{2}$ & $c_{1}=c_{2}$ \\
\hline $\mathrm{CPC}$ & $\dot{Z}_{C P C}+\dot{C}_{15}+\dot{C}_{S u n}=\dot{C}_{16}$ & $c_{\text {Sun }}=0$ \\
\hline Pump 1 & $\dot{Z}_{\text {Pump }, I}+\dot{C}_{6}+\dot{C}_{w, \text { Pump }, I}=\dot{C}_{I}$ & $c_{w, \text { Pump }, 1}=0.015\left({ }^{\$} /{ }_{M J}\right)[46]$ \\
\hline Pump 2 & $\dot{Z}_{P u m p, 2}+\dot{C}_{14}+\dot{C}_{w, \text { Pump }, 2}=\dot{C}_{15}$ & $c_{w, \text { Pump }, 1}=c_{w, \text { Pump }, 2}$ \\
\hline Condenser & $\dot{Z}_{\text {Condenser }}+\dot{C}_{4}+\dot{C}_{12}=\dot{C}_{5}+\dot{C}_{13}$ & $\begin{array}{l}c_{12}=0 \\
c_{4}=c_{5}\end{array}$ \\
\hline Evaporator & $\dot{Z}_{\text {Evaporator }}+\dot{C}_{8}+\dot{C}_{10}=\dot{C}_{9}+\dot{C}_{11}$ & $\begin{array}{l}c_{10}=0 \\
c_{8}=c_{9}\end{array}$ \\
\hline Ejector & $\dot{Z}_{\text {Ejector }}+\dot{C}_{9}+\dot{C}_{3}=\dot{C}_{4}$ & - \\
\hline Expansion valve & $\dot{Z}_{\text {Expansion valve }}+\dot{C}_{7}=\dot{C}_{8}$ & - \\
\hline
\end{tabular}

\subsection{Exergoenvironmental Modeling}

Given the importance of environmental problems in recent years, exergoenvironmental analysis has received more attention than ever before. Exergoenvironmental analysis consists of two primary parts. The first part is due to the difference between the fuel and product exergy, which is called destruction exergy, and its effects should be determined. The second one is the life cycle assessment (LCA) that is brought about by the environmental impacts. The relationship between exergy analysis and LCA analysis is used to define the environmental impact of each flow point[53].

Life cycle assessment is used to determine the environmental impact of a process. Environmental impacts are divided into three parts according to the operating time of the cycle. These three sections are operating and maintenance (OM), generation, and disposal. Among the various methods proposed for evaluation, the Eco - indicator 99 method has recently been developed and considered by many researchers. For this purpose, it has been used in the present study. The operating time of the system is considered 8760 hours, and its useful life is assumed 20 years, as well as the results are presented in the mpts unit. The Eco - indicator 99 for all equipment in the process, material, and disposal parts is shown in Table 7. Additionally, the weight functions of each component are given in Table 8 [53].

The needed heat to install the CCP cycle is provided by the solar cycle. Because different working fluids are considered, the received heat is different according to the numbers of collectors. According to Ref.[53], because the collector type is parabolic, the design is done with an effective length of $99 \mathrm{~m}$.

Exergoenvironmental balance equations are determined, according to Eq. (27)[54].

$\dot{B}_{P, k}=\dot{B}_{F, k}+\dot{Y}_{k}$

The relation of exergy and environmental impact is defined pursuant to Eq. (28)[54].

$$
\begin{aligned}
& \dot{B}_{F, k}=b_{F, k}\left(\dot{E} X_{F, k}\right) \\
& b_{F} \dot{E} X_{F}=b_{P} \dot{E} X_{P}+\dot{Y}_{k}
\end{aligned}
$$

The environmental impact of equipment is illustrated by $\dot{Y}$ that includes the process, material, and disposal parts based on LCA and follows Eq. (30).

$$
\dot{Y}^{\text {Total }}=\dot{Y}^{C O}+\dot{Y}^{O M}+\dot{Y}^{D I}
$$

In this equation, $\dot{Y}^{C O}$ is relevant to the construction environmental impact that includes manufacture and installation. $\dot{Y}^{O M}$ is operation and maintenance environmental impact, and $\dot{Y}^{D I}$ belongs to disposal environmental impact. The environment destruction exergy rate of each component is given Eq. (31)[54].

$$
\dot{B}_{D, k}=b_{F, k}\left(\dot{E} X_{D, k}\right)
$$

In order to obtain the environmental exergy rate of each flow point, the exergoenvironmental balance of all components and relevant auxiliary equations are presented in Table 9.

The components, which have the most potential to reduce the environmental impact, can be determined by the relative difference of the environmental impacts. This parameter is calculated by Eq. (32). Eq. (33) defines the total environmental impact of equipment[54].

$$
\begin{aligned}
& r_{b, k}=\frac{b_{P, k}-b_{F, k}}{b_{F, k}} \\
& \dot{B}_{\text {Total }}=\dot{B}_{D}+\dot{Y}^{\text {Total }}
\end{aligned}
$$

Eq. (34) presents an exergoenvironmental factor, which defines the component with the highest exergoenvironmental factor[54].

$$
f_{b, k}=\frac{\dot{Y}_{k}^{\text {Total }}}{\dot{B}_{D}+\dot{Y}^{\text {Total }}}
$$

The computational process conducted in the present study is shown in Figure 4. 
Table 7. Required information in LCA for each component.

\begin{tabular}{|c|c|c|c|c|}
\hline Component & Materials composition Eco'99 (mpts/kg) & $\begin{array}{l}\text { Material } \\
\text { (mpts/kg) }\end{array}$ & $\begin{array}{l}\text { Process } \\
\text { (mpts/kg) }\end{array}$ & $\begin{array}{c}\text { Disposal } \\
\text { (mpts } / \mathrm{kg})\end{array}$ \\
\hline Evaporator & Steel $100 \% 86$ & 86 & 12.1 & -70 \\
\hline Condenser & Steel $100 \% 86$ & 86 & 12.1 & -70 \\
\hline Pump & Cast iron $65 \% 240$ Steel $35 \% 86$ & 186 & 16.5 & -70 \\
\hline Steam turbine & Steel $25 \% 86$ Steel high alloy $75 \% 910$ & 704 & 12.1 & -70 \\
\hline HRVG & Steel $26 \% 86$ Steel high alloy $74 \%$ & 696 & 12.1 & -70 \\
\hline $\mathrm{CPC}$ & Steel $98 \% 86$ glass $2 \% 58$ & 85 & 7.3 & -69 \\
\hline
\end{tabular}

Table 8. Correlation weight function for equipment.

\begin{tabular}{cc}
\hline Component & Weight function (ton) \\
\hline Evaporator & $w_{\text {Evaporator }}=13.9\left(\dot{Q}^{0.68}\right), \mathrm{MW}$ \\
Condenser & $w_{\text {Condenser }}=0.073\left(\dot{Q}^{0.99}\right), \mathrm{MW}$ \\
Pump & $w_{\text {Pump }}=0.125 . \ln \left(\dot{W}^{\prime}\right)-0.041, \mathrm{~kW}$ \\
Steam turbine & $w_{\text {Turbine }}=4.9\left(\dot{W}^{0.73}\right), \mathrm{MW}$ \\
HRVG & $w_{\text {Heat recovery }}=8.42\left(\dot{Q}^{0.87}\right), \mathrm{MW}$ \\
CPC & $w_{\text {CPC }}=0.062(L), \mathrm{m}$ \\
\hline
\end{tabular}

Table 9. The exergoenvironmental balance of equipment.

\begin{tabular}{ccc}
\hline Component & Exergoenvironmental balance & Auxiliary equations \\
\hline Turbine & $\dot{Y}_{\text {Turbine }}+\dot{B}_{2}=\dot{B}_{3}+\dot{B}_{w, \text { Turbine }}$ & - \\
HRVG & $\dot{Y}_{\text {HRVG }}+\dot{B}_{1}+\dot{B}_{16}=\dot{B}_{14}+\dot{B}_{2}$ & $b_{1}=b_{2}$ \\
CPC & $\dot{Y}_{C P C}+\dot{B}_{15}+\dot{B}_{S u n}=\dot{B}_{16}$ & $b_{\text {Sun }}=0$ \\
Pump 1 & $\dot{Y}_{\text {Pump }, 1}+\dot{B}_{6}+\dot{B}_{w, \text { Pump }, 1}=\dot{B}_{1}$ & \\
Pump 2 & $\dot{Y}_{\text {Pump }, 2}+\dot{B}_{14}+\dot{B}_{w, \text { Pump }, 2}=\dot{B}_{15}$ & $b_{w, \text { Pump }, 1}=6.206(\mathrm{mpts} / \mathrm{h})[55]$ \\
Condenser & $\dot{Y}_{\text {Condenser }}+\dot{B}_{4}+\dot{B}_{12}=\dot{B}_{5}+\dot{B}_{13}$ & $b_{w, \text { Pump }, 1}=b_{w, \text { Pump }, 2}$ \\
Evaporator & $\dot{Y}_{\text {evaporator }}+\dot{B}_{8}+\dot{B}_{10}=\dot{B}_{9}+\dot{B}_{11}$ & $b_{12}=0$ \\
Ejector & $\dot{Y}_{\text {Ejector }}+\dot{B}_{9}+\dot{B}_{3}=\dot{B}_{4}$ & $b_{4}=b_{5}$ \\
Expansion valve & $\dot{Y}_{\text {Expansion valve }}+\dot{B}_{7}=\dot{B}_{8}$ & $b_{10}=0$ \\
& $b_{8}=b_{9}$ \\
\hline
\end{tabular}




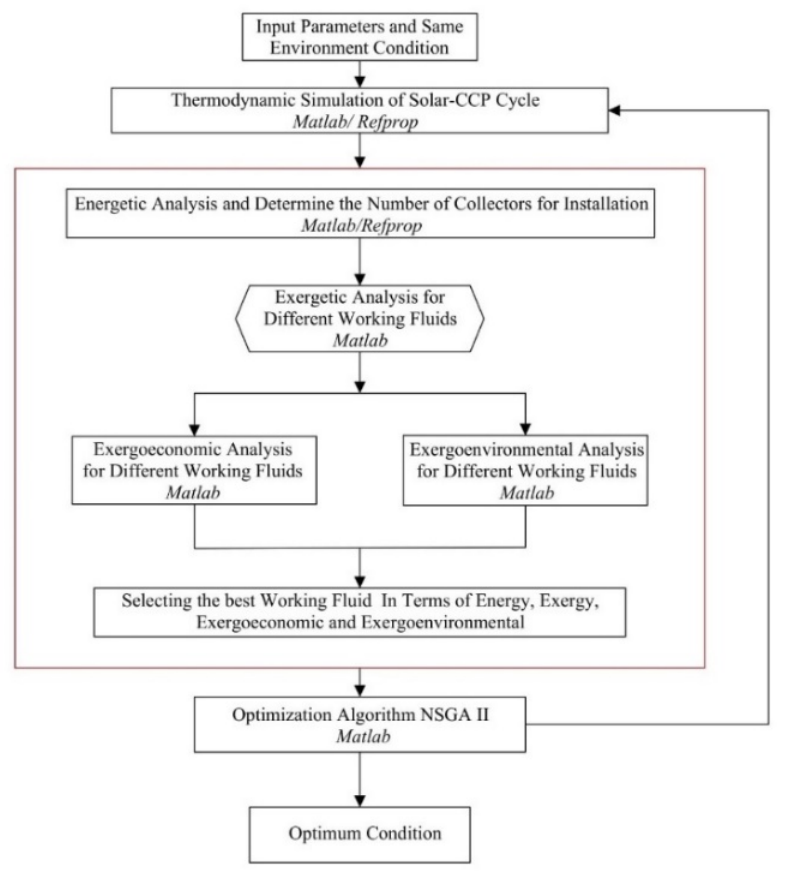

\section{Results and Discussion}

The results of energy, exergy, exergoeconomic, and exergoenvironmental analysis on the CCP cycle are presented in Tables 10-14 for each of the states. The analyzed cycle in this research is assessed with five organic working fluids include of R152A, R142b R236FA, R245fa, and R134a. The turbine inlet flow has the most pressure and enthalpy, among other flow states, because of being super-heated. Moreover, point 2, because of being super-heated, has the most cost rate and exergy rate, and among all the analyzed fluids, the most value of enthalpy, cost rate, and exergy rate are related to $\mathrm{R} 152 \mathrm{~A}$. It can be concluded that this fluid has the most capacity in the CCP cycle, and after that, there is R134a.

R245fa and R236FA have the lowest capacity among analyzed fluids. This different variable capacity can have the most impact on the exergy destruction rate of each equipment and energy and exergy efficiencies of the CCP cycle.

Figure 4. The Flowchart of the computational process.

Table 10. Thermodynamic properties of each state points of the CCP cycle for R152A.

\begin{tabular}{|c|c|c|c|c|c|c|c|c|c|}
\hline $\begin{array}{l}\text { State } \\
\text { point }\end{array}$ & Fluid & $\begin{array}{c}P \\
(\mathrm{kPa})\end{array}$ & $\begin{array}{c}T \\
(\mathrm{~K})\end{array}$ & $\begin{array}{c}h \\
(\mathrm{~kJ} / \mathrm{kg})\end{array}$ & $\begin{array}{c}s \\
(\mathrm{~kJ} / \mathrm{kg} \cdot \mathrm{K})\end{array}$ & $\begin{array}{c}\dot{m} \\
(\mathrm{~kg} / \mathrm{s})\end{array}$ & $\begin{array}{c}\dot{E X} \\
(\mathrm{~kW})\end{array}$ & $\begin{array}{c}\dot{C} \\
(\$ / h)\end{array}$ & $\begin{array}{c}\dot{B} \\
(\mathrm{mpts} / \mathrm{h})\end{array}$ \\
\hline 1 & R152A & 1200 & 304.22 & 254.92 & 1.18 & 4.5 & 284.89 & 68.15 & 6477 \\
\hline 2 & R152A & 1200 & 388 & 626.76 & 2.31 & 4.5 & 445.34 & 106.54 & 10126 \\
\hline 3 & R152A & 610 & 363.75 & 604.96 & 2.33 & 4.5 & 320.22 & 72.99 & 6948 \\
\hline 4 & R152A & 480.35 & 319.47 & 621.17 & 2.41 & 5 & 328.80 & 78.42 & 7465 \\
\hline 5 & R152A & 480.35 & 290.77 & 230.503 & 1.107 & 5 & 313.74 & 74.83 & 7123 \\
\hline 6 & $\mathrm{R} 152 \mathrm{~A}$ & 480.35 & 290.77 & 230.503 & 1.107 & 4.5 & 282.36 & 67.35 & 6410 \\
\hline 7 & $\mathrm{R} 152 \mathrm{~A}$ & 480.35 & 290.77 & 230.503 & 1.107 & 0.5 & 31.37 & 7.48 & 712.3 \\
\hline 8 & R152A & 335.69 & 280 & 230.503 & 1.19 & 0.5 & 30.24 & 7.48 & 712.3 \\
\hline 9 & $\mathrm{R} 152 \mathrm{~A}$ & 335.69 & 280 & 510.63 & 2.10 & 0.5 & 21.93 & 5.43 & 516.6 \\
\hline 10 & Water & 101 & 294.15 & 88.19 & 0.31 & 2.5 & 0.28 & 0 & 0 \\
\hline 11 & Water & 101 & 281.91 & 36.91 & 0.13 & 2.5 & 4.80 & 3.44 & 198.3 \\
\hline 12 & Water & 101 & 295 & 91.74 & 0.32 & 27 & 1.89 & 0 & 0 \\
\hline 13 & Water & 101 & 302.06 & 121.27 & 0.42 & 27 & 2.87 & 4.26 & 342 \\
\hline 14 & Water & 200 & 390 & 490.45 & 1.49 & 40 & 1985.6 & 172.54 & 16098 \\
\hline 15 & Water & 350 & 390.02 & 490.65 & 1.49 & 40 & 2229.3 & 174.27 & 16276 \\
\hline 16 & Water & 200 & 393.36 & 532.28 & 1.60 & 40 & 2388.8 & 208.95 & 19515 \\
\hline
\end{tabular}

Table 11. Thermodynamic properties of each state points of the CCP cycle for R142b.

\begin{tabular}{|c|c|c|c|c|c|c|c|c|c|}
\hline $\begin{array}{l}\text { State } \\
\text { point }\end{array}$ & Fluid & $\begin{array}{c}P \\
(\mathrm{kPa})\end{array}$ & $\begin{array}{c}T \\
(\mathrm{~K})\end{array}$ & $\begin{array}{c}h \\
(\mathrm{~kJ} / \mathrm{kg})\end{array}$ & $\begin{array}{c}s \\
(\mathrm{~kJ} / \mathrm{kg} . \mathrm{K})\end{array}$ & $\begin{array}{c}\dot{m} \\
(\mathrm{~kg} / \mathrm{s})\end{array}$ & $\begin{array}{c}\dot{E X} \\
(\mathrm{~kW})\end{array}$ & $\begin{array}{c}\dot{C} \\
(\$ / h)\end{array}$ & $\begin{array}{c}\dot{B} \\
(\mathrm{mpts} / \mathrm{h})\end{array}$ \\
\hline 1 & R142b & 1200 & 303.38 & 239.24 & 1.133 & 4.5 & 130.80 & 22.61 & 2150 \\
\hline 2 & $\mathrm{R} 142 \mathrm{~b}$ & 1200 & 388 & 508.87 & 1.915 & 4.5 & 294.86 & 50.97 & 4847 \\
\hline 3 & $\mathrm{R} 142 \mathrm{~b}$ & 610 & 366.39 & 494.85 & 1.927 & 4.5 & 214.56 & 25.37 & 2422 \\
\hline 4 & $\mathrm{R} 142 \mathrm{~b}$ & 389.75 & 306.50 & 510.70 & 1.978 & 5 & 157.56 & 26.71 & 2549 \\
\hline 5 & $\mathrm{R} 142 \mathrm{~b}$ & 389.75 & 302.88 & 238.37 & 1.132 & 5 & 141.64 & 24.01 & 2291 \\
\hline 6 & $\mathrm{R} 142 \mathrm{~b}$ & 389.75 & 302.88 & 238.37 & 1.132 & 4.5 & 127.47 & 21.61 & 2062 \\
\hline 7 & $\mathrm{R} 142 \mathrm{~b}$ & 389.75 & 302.88 & 238.37 & 1.132 & 0.5 & 14.16 & 2.40 & 229.2 \\
\hline 8 & $\mathrm{R} 142 \mathrm{~b}$ & 185.59 & 280 & 238.37 & 1.137 & 0.5 & 13.45 & 2.40 & 229.2 \\
\hline 9 & $\mathrm{R} 142 \mathrm{~b}$ & 185.59 & 280 & 422.47 & 1.794 & 0.5 & 7.48 & 1.33 & 127.5 \\
\hline 10 & Water & 101 & 294.15 & 88.19 & 0.310 & 2.5 & 0.28 & 0 & 0 \\
\hline 11 & Water & 101 & 285.35 & 51.37 & 0.183 & 2.5 & 2.95 & 1.75 & 103.7 \\
\hline 12 & Water & 101 & 295 & 91.74 & 0.322 & 27 & 1.89 & 0 & 0 \\
\hline 13 & Water & 101 & 303.96 & 129.21 & 0.447 & 27 & 6.31 & 3.44 & 257.7 \\
\hline 14 & Water & 200 & 390 & 490.45 & 1.493 & 40 & 1985.6 & 173.65 & 16202 \\
\hline 15 & Water & 350 & 390.02 & 490.65 & 1.493 & 40 & 2229.3 & 175.39 & 16380 \\
\hline 16 & Water & 200 & 393.36 & 520.78 & 1.571 & 40 & 2277.5 & 200.49 & 18724 \\
\hline
\end{tabular}


Table 12. Thermodynamic properties of each state points of the CCP cycle for R236FA.

\begin{tabular}{|c|c|c|c|c|c|c|c|c|c|}
\hline $\begin{array}{l}\text { State } \\
\text { point }\end{array}$ & Fluid & $\begin{array}{c}P \\
(\mathrm{kPa})\end{array}$ & $\begin{array}{c}T \\
(\mathrm{~K})\end{array}$ & $\begin{array}{c}h \\
(\mathrm{~kJ} / \mathrm{kg})\end{array}$ & $\begin{array}{c}s \\
(\mathrm{~kJ} / \mathrm{kg} \cdot \mathrm{K})\end{array}$ & $\begin{array}{c}\dot{m} \\
(\mathrm{~kg} / \mathrm{s})\end{array}$ & $\begin{array}{c}\dot{E X} \\
(\mathrm{~kW})\end{array}$ & $\begin{array}{c}\dot{C} \\
(\$ / h)\end{array}$ & $\begin{array}{c}\dot{B} \\
(\mathrm{mpts} / \mathrm{h})\end{array}$ \\
\hline 1 & R236FA & 1200 & 301.36 & 234.55 & 1.11 & 4.5 & 71.68 & 12.22 & 1163 \\
\hline 2 & R236FA & 1200 & 388 & 448.56 & 1.73 & 4.5 & 205.87 & 35.10 & 3342 \\
\hline 3 & R236FA & 550 & 396.77 & 437.97 & 1.74 & 4.5 & 145.31 & 21.19 & 2034 \\
\hline 4 & R236FA & 297.37 & 384.19 & 454.98 & 1.82 & 5 & 131.97 & 21.71 & 2083 \\
\hline 5 & R236FA & 297.37 & 300.85 & 233.77 & 1.11 & 5 & 76.30 & 12.55 & 1204 \\
\hline 6 & R236FA & 297.37 & 300.85 & 233.77 & 1.11 & 4.5 & 68.67 & 11.29 & 1084 \\
\hline 7 & R236FA & 297.37 & 300.85 & 233.77 & 1.11 & 0.5 & 7.63 & 1.255 & 120.4 \\
\hline 8 & R236FA & 141.60 & 280 & 233.77 & 1.12 & 0.5 & 7.08 & 1.26 & 120.4 \\
\hline 9 & R236FA & 141.60 & 280 & 363.36 & 1.58 & 0.5 & 2.88 & 0.51 & 49.1 \\
\hline 10 & Water & 101 & 294.15 & 88.19 & 0.31 & 2.5 & 0.28 & 0 & 0 \\
\hline 11 & Water & 101 & 187.95 & 62.27 & 0.22 & 2.5 & 1.86 & 1.16 & 73.1 \\
\hline 12 & Water & 101 & 295 & 91.74 & 0.32 & 27 & 1.89 & 0 & 0 \\
\hline 13 & Water & 101 & 304.79 & 132.71 & 0.45 & 27 & 8.24 & 9.42 & 879 \\
\hline 14 & Water & 200 & 390 & 490.45 & 1.49 & 40 & 1985.6 & 174.73 & 16302 \\
\hline 15 & Water & 350 & 390.02 & 490.65 & 1.49 & 40 & 2229.3 & 176.46 & 16480 \\
\hline 16 & Water & 200 & 393.36 & 514.53 & 1.55 & 40 & 2216.9 & 196.35 & 18338 \\
\hline
\end{tabular}

Table 13. Thermodynamic properties of each state points of the CCP cycle for R245fa.

\begin{tabular}{|c|c|c|c|c|c|c|c|c|c|}
\hline $\begin{array}{l}\text { State } \\
\text { point }\end{array}$ & Fluid & $\begin{array}{c}P \\
(\mathrm{kPa})\end{array}$ & $\begin{array}{c}T \\
(\mathrm{~K})\end{array}$ & $\begin{array}{c}h \\
(\mathrm{~kJ} / \mathrm{kg})\end{array}$ & $\begin{array}{c}s \\
(\mathrm{~kJ} / \mathrm{kg} \cdot \mathrm{K})\end{array}$ & $\begin{array}{c}\dot{m} \\
(\mathrm{~kg} / \mathrm{s})\end{array}$ & $\begin{array}{c}\dot{E} X \\
(\mathrm{~kW})\end{array}$ & $\begin{array}{c}\dot{C} \\
(\$ / h)\end{array}$ & $\begin{array}{c}\dot{B} \\
(\mathrm{mpts} / \mathrm{h})\end{array}$ \\
\hline 1 & $\mathrm{R} 245 \mathrm{fa}$ & 1200 & 299.05 & 233.96 & 1.115 & 4.5 & 33.83 & 4.843 & 461.3 \\
\hline 2 & $\mathrm{R} 245 \mathrm{fa}$ & 1200 & 388 & 494.78 & 1.847 & 4.5 & 225.65 & 32.301 & 3076 \\
\hline 3 & $\mathrm{R} 245 \mathrm{fa}$ & 400 & 360.15 & 478.23 & 1.863 & 4.5 & 130.47 & 5.305 & 514.6 \\
\hline 4 & $\mathrm{R} 245 \mathrm{fa}$ & 150.68 & 321.31 & 494.77 & 1.921 & 5 & 39.15 & 4.904 & 475.5 \\
\hline 5 & $\mathrm{R} 245 \mathrm{fa}$ & 150.68 & 298.59 & 233.03 & 1.115 & 5 & 33.67 & 4.218 & 408.9 \\
\hline 6 & $\mathrm{R} 245 \mathrm{fa}$ & 150.68 & 298.59 & 233.03 & 1.115 & 4.5 & 30.30 & 3.796 & 368.1 \\
\hline 7 & $\mathrm{R} 245 \mathrm{fa}$ & 150.68 & 298.59 & 233.03 & 1.115 & 0.5 & 3.336 & 0.421 & 40.8 \\
\hline 8 & $\mathrm{R} 245 \mathrm{fa}$ & 71.75 & 280 & 233.03 & 1.118 & 0.5 & 2.92 & 0.426 & 40.8 \\
\hline 9 & $\mathrm{R} 245 \mathrm{fa}$ & 71.75 & 280 & 409.47 & 1.745 & 0.5 & -2.79 & -0.407 & -39 \\
\hline 10 & Water & 101 & 294.15 & 88.19 & 0.310 & 2.5 & 0.28 & 0 & 0 \\
\hline 11 & Water & 101 & 285.72 & 52.90 & 0.189 & 2.5 & 2.78 & 1.474 & 82.1 \\
\hline 12 & Water & 101 & 295 & 91.74 & 0.322 & 27 & 1.89 & 0 & 0 \\
\hline 13 & Water & 101 & 304.37 & 130.95 & 0.453 & 27 & 7.24 & 1.222 & 66.6 \\
\hline 14 & Water & 200 & 390 & 490.45 & 1.493 & 40 & 2226.7 & 173.796 & 16215 \\
\hline 15 & Water & 350 & 390.02 & 490.65 & 1.494 & 40 & 1992.3 & 175.529 & 16393 \\
\hline 16 & Water & 200 & 393.36 & 519.79 & 1.568 & 40 & 2267.9 & 199.804 & 18660 \\
\hline
\end{tabular}

Table 14. Thermodynamic properties of each state points of the CCP cycle for R134a.

\begin{tabular}{|c|c|c|c|c|c|c|c|c|c|}
\hline $\begin{array}{l}\text { State } \\
\text { point }\end{array}$ & Fluid & $\begin{array}{c}P \\
(\mathrm{kPa})\end{array}$ & $\begin{array}{c}T \\
(\mathrm{~K})\end{array}$ & $\begin{array}{c}h \\
(\mathrm{~kJ} / \mathrm{kg})\end{array}$ & $\begin{array}{c}s \\
(\mathrm{~kJ} / \mathrm{kg} \cdot \mathrm{K})\end{array}$ & $\begin{array}{c}\dot{m} \\
(\mathrm{~kg} / \mathrm{s})\end{array}$ & $\begin{array}{c}E X \\
(\mathrm{~kW})\end{array}$ & $\begin{array}{c}\dot{C} \\
(\$ / \mathrm{h})\end{array}$ & $\begin{array}{c}\dot{B} \\
(\mathrm{mpts} / \mathrm{h})\end{array}$ \\
\hline 1 & R134a & 1200 & 304.006 & 242.94 & 1.146 & 4.5 & 195.21 & 50.87 & 4837 \\
\hline 2 & R134a & 1200 & 388 & 496.73 & 1.920 & 4.5 & 298.09 & 77.69 & 7387 \\
\hline 3 & R134a & 750 & 373.88 & 486.75 & 1.929 & 4.5 & 241.18 & 57.97 & 5527 \\
\hline 4 & R134a & 603.24 & 321.94 & 497.20 & 1.983 & 5 & 239.24 & 62.16 & 5926 \\
\hline 5 & R134a & 603.24 & 294.77 & 229.75 & 1.103 & 5 & 215.13 & 55.90 & 5328 \\
\hline 6 & R134a & 603.24 & 294.77 & 229.75 & 1.103 & 4.5 & 193.62 & 50.31 & 4769 \\
\hline 7 & $\mathrm{R} 134 \mathrm{a}$ & 603.24 & 294.77 & 229.75 & 1.103 & 0.5 & 21.51 & 5.59 & 532.8 \\
\hline 8 & R134a & 372.70 & 280 & 229.75 & 1.152 & 0.5 & 20.62 & 5.59 & 532.8 \\
\hline 9 & R134a & 372.70 & 280 & 402.54 & 1.723 & 0.5 & 15.44 & 4.18 & 398.9 \\
\hline 10 & Water & 101 & 294.15 & 88.19 & 0.310 & 2.5 & 0.28 & 0 & 0 \\
\hline 11 & Water & 101 & 286.50 & 56.18 & 0.2005 & 2.5 & 2.44 & 1.95 & 135.9 \\
\hline 12 & Water & 101 & 295 & 91.74 & 0.322 & 27 & 1.89 & 0 & 0 \\
\hline 13 & Water & 101 & 303.88 & 128.87 & 0.446 & 27 & 6.13 & 6.61 & 597.1 \\
\hline 14 & Water & 200 & 390 & 490.45 & 1.493 & 40 & 1985.6 & 173.91 & 1622 \\
\hline 15 & Water & 350 & 390.02 & 490.65 & 1.493 & 40 & 2229.3 & 175.64 & 1640 \\
\hline 16 & Water & 200 & 393.36 & 519.004 & 1.566 & 40 & 2260.2 & 199.26 & 1861 \\
\hline
\end{tabular}

\subsection{The Results of Exergy Analysis}

Input conditions for all of the fluids are the same, but according to their different thermodynamic properties, each component's exergy fuel and exergy product are different. The results of the exergy analysis for each of the components are presented in Tables 15-19. In all the fluids, HRVG, whose task is to transfer the heat from the solar system to the CCP cycle, and CPC have the most value of exergy destruction rate. The most obtained exergy destruction rate for these two components is for R152A and R134a. By decreasing the irreversibility, the efficiency of the cycle will be increased. 
Table 15. Results of exergy analysis for each component for the $R 152 \mathrm{~A}$.

\begin{tabular}{cccc}
\hline Component & $\dot{E} X_{F}(\mathrm{~kW})$ & $\dot{E} X_{P}(\mathrm{~kW})$ & $\dot{E} X_{D}(\mathrm{~kW})$ \\
\hline Condenser & 15.062 & 0.980 & 14.082 \\
CPC & 187.14 & 159.51 & 27.62 \\
Ejector & 342.154 & 328.805 & 13.349 \\
Evaporator & 8.309 & 4.525 & 3.783 \\
HRVG & 403.187 & 160.454 & 242.733 \\
Pump 1 & 2.960 & 2.525 & 0.435 \\
Pump 2 & 7.930 & 6.718 & 1.212 \\
Turbine & 125.125 & 98.106 & 27.019 \\
Expansion valve & 31.374 & 30.241 & 1.132 \\
\hline
\end{tabular}

Table 16. Results of exergy analysis for each component for the $R 142 b$.

\begin{tabular}{|c|c|c|c|}
\hline Component & $\dot{E} X_{F}(\mathrm{~kW})$ & $\dot{E} X_{P}(\mathrm{~kW})$ & $\dot{E} X_{D}(\mathrm{~kW})$ \\
\hline Condenser & 15.062 & 0.980 & 14.082 \\
\hline $\mathrm{CPC}$ & 187.14 & 159.51 & 27.62 \\
\hline Ejector & 342.154 & 328.805 & 13.349 \\
\hline Evaporator & 8.309 & 4.525 & 3.783 \\
\hline HRVG & 403.187 & 160.454 & 242.733 \\
\hline Pump 1 & 2.960 & 2.525 & 0.435 \\
\hline Pump 2 & 7.930 & 6.718 & 1.212 \\
\hline Turbine & 125.125 & 98.106 & 27.019 \\
\hline Expansion valve & 31.374 & 30.241 & 1.132 \\
\hline
\end{tabular}

Table 17. Results of exergy analysis for each component

\begin{tabular}{cccc}
\multicolumn{4}{c}{ for the R236FA. } \\
\hline Component & $\dot{E} X_{F}(\mathrm{~kW})$ & $\dot{E} X_{P}(\mathrm{~kW})$ & $\dot{E} X_{D}(\mathrm{~kW})$ \\
\hline Condenser & 15.062 & 0.980 & 14.082 \\
CPC & 187.14 & 159.51 & 27.62 \\
Ejector & 342.154 & 328.805 & 13.349 \\
Evaporator & 8.309 & 4.525 & 3.783 \\
HRVG & 403.187 & 160.454 & 242.733 \\
Pump 1 & 2.960 & 2.525 & 0.435 \\
Pump 2 & 7.930 & 6.718 & 1.212 \\
Turbine & 125.125 & 98.106 & 27.019 \\
Expansion valve & 31.374 & 30.241 & 1.132 \\
\hline
\end{tabular}

Table 18. Results of exergy analysis for each component for the R245fa.

\begin{tabular}{cccc}
\hline Component & $\dot{E} X_{F}(\mathrm{~kW})$ & $\dot{E} X_{P}(\mathrm{~kW})$ & $\dot{E} X_{D}(\mathrm{~kW})$ \\
\hline Condenser & 15.062 & 0.980 & 14.082 \\
CPC & 187.14 & 159.51 & 27.62 \\
Ejector & 342.154 & 328.805 & 13.349 \\
Evaporator & 8.309 & 4.525 & 3.783 \\
HRVG & 403.187 & 160.454 & 242.733 \\
Pump 1 & 2.960 & 2.525 & 0.435
\end{tabular}

\begin{tabular}{cccc} 
Pump 2 & 7.930 & 6.718 & 1.212 \\
Turbine & 125.125 & 98.106 & 27.019 \\
Expansion valve & 31.374 & 30.241 & 1.132 \\
\hline
\end{tabular}

Table 19. Results of exergy analysis for each component for the R134a.

\begin{tabular}{cccc}
\hline Component & $\dot{E} X_{F}(\mathrm{~kW})$ & $\dot{E} X_{P}(\mathrm{~kW})$ & $\dot{E} X_{D}(\mathrm{~kW})$ \\
\hline Condenser & 15.062 & 0.980 & 14.082 \\
CPC & 187.14 & 159.51 & 27.62 \\
Ejector & 342.154 & 328.805 & 13.349 \\
Evaporator & 8.309 & 4.525 & 3.783 \\
HRVG & 403.187 & 160.454 & 242.733 \\
Pump 1 & 2.960 & 2.525 & 0.435 \\
Pump 2 & 7.930 & 6.718 & 1.212 \\
Turbine & 125.125 & 98.106 & 27.019 \\
Expansion valve & 31.374 & 30.241 & 1.132 \\
\hline
\end{tabular}

\subsection{The Results of Exergoeconomic Analysis}

The results of exergoeconomic analysis for each of the fluids are presented in Tables 20-24. By calculating the unit cost of exergy of each of the state flows, the cost rates of fuel, product, and destruction of all the components in the CCP cycle will be calculated. The total cost rate consists of the sum of loss cost rate, exergy destruction cost rate, and investment cost rate. The loss cost rate is ignored in this research. The most value of exergy destruction cost rate for $\mathrm{R} 152 \mathrm{~A}$ is related to the CPC.

Relative cost deference of each equipment is calculated according to Eq. (25). After CPC, which has the most value among all the fluids, the condenser with R152A and R236FA as well as the pump 1 with R142b, $\mathrm{R} 245 \mathrm{fa}$, and R134a have the second place. This parameter's high value can be caused by the investment cost rate and exergy destruction cost rate. In order to distinguish this topic, the exergoeconomic factor concept is used. For R152A and R236FA, this condenser value is low, indicating the high-cost rate of exergy destruction in this component according to the high heat transmission. Additionally, in R142b, R245fa, R134a fluids, the pump has high exergoeconomic factors that make it clear that the high-acquired relative cost deference is because of the high investment cost rate according to its work.

Table 20. The exergoeconomic results of each component for $R 152 \mathrm{~A}$.

\begin{tabular}{|c|c|c|c|c|c|c|c|c|c|}
\hline Component & $\begin{array}{l}c_{F} \\
(\$ / \mathrm{MJ})\end{array}$ & $\begin{array}{l}c_{P} \\
(\$ / \mathrm{MJ})\end{array}$ & $\begin{array}{l}\dot{C}_{F} \\
(\$ / \mathrm{h})\end{array}$ & $\begin{array}{l}\dot{C}_{P} \\
(\$ / \mathrm{h})\end{array}$ & $\begin{array}{l}\dot{C}_{D} \\
(\$ / \mathrm{h})\end{array}$ & $\begin{array}{l}\dot{Z} \\
(\$ / h)\end{array}$ & $\begin{array}{l}\dot{C}_{D}+\dot{Z} \\
(\$ / \mathrm{h})\end{array}$ & $\begin{array}{c}r \\
(\%)\end{array}$ & $\begin{array}{c}f \\
(\%) \\
\end{array}$ \\
\hline Condenser & 0.066 & 1.207 & 3.592 & 4.262 & 61.234 & 0.669 & 61.904 & 1723.07 & 1.08 \\
\hline $\mathrm{CPC}$ & 0 & 0.024 & 0 & 34.679 & 78.691 & 34.679 & 113.371 & Infinity & 30.58 \\
\hline Ejector & 0.063 & 0.066 & 78.424 & 78.426 & 3.184 & 0.002 & 3.186 & 4.062 & 0.06 \\
\hline Evaporator & 0.068 & 0.211 & 2.057 & 3.449 & 2.884 & 1.392 & 4.276 & 207.850 & 32.55 \\
\hline HRVG & 0.025 & 0.066 & 36.412 & 38.387 & 58.071 & 1.975 & 60.046 & 164.908 & 3.289 \\
\hline Pump 1 & 0.015 & 0.088 & 0.159 & 0.807 & 0.139 & 0.647 & 0.786 & 492.280 & 82.31 \\
\hline Pump 2 & 0.015 & 0.071 & 0.428 & 1.732 & 0.312 & 1.304 & 1.616 & 377.478 & 80.66 \\
\hline Turbine & 0.074 & 0.121 & 33.551 & 42.795 & 11.786 & 9.244 & 21.030 & 62.682 & 43.95 \\
\hline $\begin{array}{l}\text { Expansion } \\
\text { valve }\end{array}$ & 0.066 & 0.068 & 7.483 & 7.488 & 0.280 & 0.004 & 0.285 & 3.813 & 1.69 \\
\hline
\end{tabular}

Table 21. The exergoeconomic results of each component for $R 142 b$.

\begin{tabular}{|c|c|c|c|c|c|c|c|c|c|}
\hline Component & $\begin{array}{l}c_{F} \\
(\$ / \mathrm{MJ})\end{array}$ & $\begin{array}{l}c_{P} \\
(\$ / \mathrm{MJ})\end{array}$ & $\begin{array}{l}\dot{C}_{F} \\
(\$ / \mathrm{h})\end{array}$ & $\begin{array}{l}\dot{C}_{P} \\
(\$ / \mathrm{h})\end{array}$ & $\begin{array}{l}\dot{C}_{D} \\
(\$ / \mathrm{h})\end{array}$ & $\begin{array}{l}\dot{Z} \\
(\$ / h)\end{array}$ & $\begin{array}{l}\dot{C}_{D}+\dot{Z} \\
(\$ / \mathrm{h})\end{array}$ & $\begin{array}{c}r \\
(\%) \\
\end{array}$ & $\begin{array}{c}f \\
(\%)\end{array}$ \\
\hline Condenser & 0.047 & 0.216 & 2.7006 & 3.447 & 8.980 & 0.747 & 9.727 & 360.19 & 7.68 \\
\hline $\mathrm{CPC}$ & 0 & 0.024 & 0 & 25.101 & 57.482 & 25.101 & 82.583 & Infinity & 30.39 \\
\hline Ejector & 0.033 & 0.047 & 26.713 & 26.716 & 10.933 & 0.003 & 10.936 & 40.94 & 0.02 \\
\hline Evaporator & 0.049 & 0.182 & 1.067 & 1.752 & 2.156 & 0.685 & 2.841 & 266.20 & 24.11 \\
\hline HRVG & 0.025 & 0.048 & 26.833 & 28.362 & 22.092 & 1.528 & 23.621 & 88.02 & 6.47 \\
\hline Pump 1 & 0.015 & 0.083 & 0.210 & 0.998 & 0.172 & 0.787 & 0.960 & 456.07 & 82.02 \\
\hline Pump 2 & 0.015 & 0.071 & 0.428 & 1.732 & 0.312 & 1.304 & 1.616 & 377.47 & 80.66 \\
\hline Turbine & 0.088 & 0.142 & 25.6007 & 32.386 & 8.841 & 6.786 & 15.627 & 61.04 & 43.42 \\
\hline $\begin{array}{l}\text { Expansion } \\
\text { valve }\end{array}$ & 0.047 & 0.049 & 2.401 & 2.406 & 0.127 & 0.004 & 0.132 & 5.49 & 3.67 \\
\hline
\end{tabular}


Table 22. The exergoeconomic results of each component for $R 236 F A$.

\begin{tabular}{|c|c|c|c|c|c|c|c|c|c|}
\hline Component & $\begin{array}{l}c_{F} \\
(\$ / \mathrm{MJ})\end{array}$ & $\begin{array}{l}c_{P} \\
(\$ / \mathrm{MJ})\end{array}$ & $\begin{array}{l}\dot{C}_{F} \\
(\$ / \mathrm{h})\end{array}$ & $\begin{array}{l}\dot{C}_{P} \\
(\$ / \mathrm{h})\end{array}$ & $\begin{array}{l}\dot{C}_{D} \\
(\$ / \mathrm{h})\end{array}$ & $\begin{array}{l}\dot{Z} \\
(\$ / h)\end{array}$ & $\begin{array}{l}\dot{C}_{D}+\dot{Z} \\
(\$ / \mathrm{h})\end{array}$ & $\begin{array}{c}r \\
(\%) \\
\end{array}$ & $\begin{array}{c}f \\
(\%)\end{array}$ \\
\hline Condenser & 0.045 & 0.412 & 9.158 & 9.427 & 73.210 & 0.269 & 73.480 & 802.35 & 0.36 \\
\hline $\mathrm{CPC}$ & 0 & 0.024 & 0 & 19.889 & 45.947 & 19.889 & 65.836 & Infinity & 30.21 \\
\hline Ejector & 0.040 & 0.045 & 21.707 & 21.711 & 2.670 & 0.003 & 2.674 & 12.32 & 0.14 \\
\hline Evaporator & 0.049 & 0.203 & 0.745 & 1.160 & 1.919 & 0.413 & 2.333 & 312.50 & 17.73 \\
\hline HRVG & 0.026 & 0.047 & 21.621 & 22.882 & 16.554 & 1.260 & 17.815 & 82.39 & 7.07 \\
\hline Pump 1 & 0.015 & 0.085 & 0.190 & 0.925 & 0.161 & 0.734 & 0.895 & 469.41 & 81.99 \\
\hline Pump 2 & 0.015 & 0.071 & 0.428 & 1.732 & 0.312 & 1.304 & 1.616 & 377.47 & 80.66 \\
\hline Turbine & 0.063 & 0.113 & 13.911 & 19.490 & 5.263 & 5.578 & 10.842 & 77.94 & 51.45 \\
\hline $\begin{array}{l}\text { Expansion } \\
\text { valve }\end{array}$ & 0.045 & 0.049 & 1.255 & 1.260 & 0.096 & 0.004 & 0.101 & 8.07 & 4.78 \\
\hline
\end{tabular}

Table 23. The exergoeconomic results of each component for $R 245 \mathrm{fa}$.

\begin{tabular}{cccccccccc}
\hline Component & $\begin{array}{c}c_{F} \\
(\$ / \mathrm{MJ})\end{array}$ & $\begin{array}{c}c_{P} \\
(\$ / \mathrm{MJ})\end{array}$ & $\begin{array}{c}\dot{C}_{F} \\
(\$ / \mathrm{h})\end{array}$ & $\begin{array}{c}\dot{C}_{P} \\
(\$ / \mathrm{h})\end{array}$ & $\begin{array}{c}\dot{C}_{D} \\
(\$ / \mathrm{h})\end{array}$ & $\begin{array}{c}\dot{Z} \\
(\$ / \mathrm{h})\end{array}$ & $\begin{array}{c}\dot{C}_{D}+\dot{Z} \\
(\$ / \mathrm{h})\end{array}$ & $\begin{array}{c}r \\
(\%)\end{array}$ & $\begin{array}{c}f \\
(\%)\end{array}$ \\
\hline Condenser & 0.034 & 0.063 & 0.686 & 1.222 & 0.030 & 0.535 & 0.565 & 82.41 \\
CPC & 0 & 0.024 & 0 & 24.275 & 55.655 & 24.275 & 79.931 & Infinity & 30.65 \\
Ejector & 0.010 & 0.034 & 4.898 & 4.904 & 11.088 & 0.006 & 11.095 & 226.53 & 0.05 \\
Evaporator & 0.040 & 0.163 & 0.834 & 1.474 & 1.889 & 0.639 & 2.529 & 303.21 & 25.29 \\
HRVG & 0.025 & 0.039 & 26.008 & 27.458 & 12.947 & 1.450 & 14.397 & 55.35 & 10.07 \\
Pump 1 & 0.015 & 0.082 & 0.224 & 1.047 & 0.184 & 0.823 & 1.007 & 449.58 & 81.71 \\
Pump 2 & 0.015 & 0.071 & 0.428 & 1.732 & 0.312 & 1.304 & 1.616 & 377.47 & 80.66 \\
Turbine & 0.078 & 0.129 & 26.996 & 34.618 & 9.623 & 7.622 & 17.245 & 63.88 & 44.19 \\
Expansion & 0.034 & 0.040 & 0.421 & 0.426 & 0.064 & 0.004 & 0.069 & 16.45 & 6.98 \\
valve & & & & & & & & &
\end{tabular}

Table 24. The exergoeconomic results of each component for R134a.

\begin{tabular}{|c|c|c|c|c|c|c|c|c|c|}
\hline Component & $\begin{array}{l}c_{F} \\
(\$ / \mathrm{MJ})\end{array}$ & $\begin{array}{l}c_{P} \\
(\$ / \mathrm{MJ})\end{array}$ & $\begin{array}{l}\dot{C}_{F} \\
(\$ / \mathrm{h})\end{array}$ & $\begin{array}{l}\dot{C}_{P} \\
(\$ / \mathrm{h})\end{array}$ & $\begin{array}{l}\dot{C}_{D} \\
(\$ / \mathrm{h})\end{array}$ & $\begin{array}{l}\dot{Z} \\
(\$ / \mathrm{h})\end{array}$ & $\begin{array}{l}\dot{C}_{D}+\dot{Z} \\
(\$ / \mathrm{h})\end{array}$ & $\begin{array}{c}r \\
(\%) \\
\end{array}$ & $\begin{array}{c}f \\
(\%)\end{array}$ \\
\hline Condenser & 0.072 & 0.433 & 6.263 & 6.618 & 30.973 & 0.354 & 31.328 & 500.13 & 1.13 \\
\hline $\mathrm{CPC}$ & 0 & 0.024 & 0 & 23.616 & 54.195 & 23.616 & 77.811 & Infinity & 30.35 \\
\hline Ejector & 0.067 & 0.072 & 62.163 & 62.165 & 4.516 & 0.0019 & 4.518 & $7.26^{\circ}$ & 0.04 \\
\hline Evaporator & 0.075 & 0.251 & 1.406 & 1.958 & 2.742 & 0.551 & 3.294 & 234.19 & 16.75 \\
\hline HRVG & 0.025 & 0.072 & 25.348 & 26.812 & 44.754 & 1.464 & 46.218 & 182.33 & 3.16 \\
\hline Pump 1 & 0.015 & 0.099 & 0.1006 & 0.566 & 0.097 & 0.466 & 0.563 & 560.67 & 82.66 \\
\hline Pump 2 & 0.015 & 0.071 & 0.428 & 1.732 & 0.312 & 1.304 & 1.616 & 377.47 & 80.66 \\
\hline Turbine & 0.096 & 0.155 & 19.715 & 25.065 & 6.691 & 5.350 & 12.042 & 61.07 & 44.42 \\
\hline $\begin{array}{l}\text { Expansion } \\
\text { valve }\end{array}$ & 0.072 & 0.075 & 5.590 & 5.595 & 0.240 & 0.0048 & 0.245 & 4.39 & 1.97 \\
\hline
\end{tabular}

\subsection{The Results of Exergoenvironmental Analysis}

The results of exergoenvironmental analysis with different working fluids are shown in Tables 25-29. The highest value of environmental impact is related to CPC for R152A. Moreover, the high environmental impact rate associated with exergy or component-related environmental impacts indicates these components have a high potential to improve their environmental condition. The reason that makes these working fluids more significant is the low product environmental impact in the analyzed cycle related to the turbine and the evaporator. The lowest obtained rate is associated with R236FA.

The environmental impacts of consumed electricity in the pump are considered 6.206(mpts/MJ)[55]. The exergoenvironmental factor of each component is calculated by Eq. (35), and the most exergoenvironmental factor rate in all the fluids is related to CPC and HRVG. Due to the fact that it can be concluded that in order to decrease the environmental impact of these components, their substructure process like fabrication and disposal should be changed. The most relative environmental impact difference in all fluids is related to CPC, indicating the high importance of its environmental impact compared to other components. This analysis suggests that increasing destruction exergy will increase the environmental effect in an unfavorable factor in cycle designing.

Table 25. The exergoenvironmental results of each component for R152A.

\begin{tabular}{|c|c|c|c|c|c|c|c|c|c|}
\hline Component & $\begin{array}{c}b_{F} \\
(\mathrm{mpts} / \mathrm{MJ})\end{array}$ & $\begin{array}{c}b_{P} \\
(\mathrm{mpts} / \mathrm{MJ})\end{array}$ & $\begin{array}{c}\dot{B}_{F} \\
(\mathrm{mpts} / \mathrm{h})\end{array}$ & $\begin{array}{c}\dot{B}_{P} \\
(\mathrm{mpts} / \mathrm{h}\end{array}$ & $\begin{array}{c}\dot{B}_{D} \\
(\mathrm{mpts} / \mathrm{h})\end{array}$ & $\begin{array}{c}\dot{Y} \\
(\mathrm{mpts} / \mathrm{h})\end{array}$ & $\begin{array}{c}\dot{B}_{D}+\dot{Y} \\
(\mathrm{mpts} / \mathrm{h})\end{array}$ & $\begin{array}{c}r_{B} \\
(\%)\end{array}$ & $\begin{array}{l}f_{B} \\
(\%)\end{array}$ \\
\hline Condenser & 6.3 & 96.92 & 341.97 & 342.02 & 4913 & 1.63 & 4914.6 & 1436 & 0.004 \\
\hline $\mathrm{CPC}$ & 0 & 2.26 & 0 & 3238 & 7349 & 3238 & 10587 & Infinity & 30.58 \\
\hline Ejector & 6.06 & 6.30 & 7465.2 & 7465.2 & 303.1 & 0 & 303.1 & $4.05^{\circ}$ & 0 \\
\hline Evaporator & 6.54 & 12.17 & 195.7 & 198.3 & 165.86 & 2.64 & 168.41 & 86.1 & 1.57 \\
\hline HRVG & 2.35 & 6.31 & 3416 & 3648 & 5518 & 231.3 & 5749.3 & 168.2 & 4.02 \\
\hline Pump 1 & 6.206 & 7.31 & 66.13 & 66.47 & 11.45 & 0.34 & 11.79 & 17.84 & 2.91 \\
\hline Pump 2 & 6.206 & 7.35 & 177.1 & 177.98 & 32.12 & 0.79 & 32.91 & 18.57 & 2.4 \\
\hline Turbine & 7.05 & 9.04 & 3176 & 3192 & 879.3 & 15.98 & 895.2 & 28.18 & 1.78 \\
\hline $\begin{array}{c}\text { Expansion } \\
\text { valve }\end{array}$ & 6.3 & 6.5 & 712.3 & 712.3 & 26.68 & 0 & 26.68 & 3.74 & 0 \\
\hline
\end{tabular}


Table 26. The exergoenvironmental results of each component for $R 142 b$.

\begin{tabular}{|c|c|c|c|c|c|c|c|c|c|}
\hline Component & $\begin{array}{c}b_{F} \\
(\mathrm{mpts} / \mathrm{MJ})\end{array}$ & $\begin{array}{c}b_{P} \\
(\mathrm{mpts} / \mathrm{MJ})\end{array}$ & $\begin{array}{c}\dot{B}_{F} \\
(\mathrm{mpts} / \mathrm{h})\end{array}$ & $\begin{array}{c}\dot{B}_{P} \\
(\mathrm{mpts} / \mathrm{h}\end{array}$ & $\begin{array}{c}\dot{B}_{D} \\
(\mathrm{mpts} / \mathrm{h})\end{array}$ & $\begin{array}{c}\dot{Y} \\
(\mathrm{mpts} / \mathrm{h})\end{array}$ & $\begin{array}{c}\dot{B}_{D}+\dot{Y} \\
(\mathrm{mpts} / \mathrm{h})\end{array}$ & $\begin{array}{c}r_{B} \\
(\%)\end{array}$ & $\begin{array}{l}f_{B} \\
(\%)\end{array}$ \\
\hline Condenser & 4.49 & 16.2 & 257.73 & 257.78 & 671.4 & 0.05 & 671.45 & 260.5 & 0.008 \\
\hline $\mathrm{CPC}$ & 0 & 2.28 & 0 & 2344 & 5368 & 2344 & 7712 & Infinity & 30.39 \\
\hline Ejector & 3.18 & 4.49 & 2549 & 2549 & 1043 & 0 & 1043 & 40.92 & 0 \\
\hline Evaporator & 4.7 & 10.77 & 101.6 & 103.7 & 127.6 & 2.11 & 129.71 & 127.7 & 1.62 \\
\hline HRVG & 2.4 & 4.56 & 2522 & 2697 & 2109 & 174.8 & 2283.8 & 90.22 & 7.68 \\
\hline Pump 1 & 6.206 & 7.31 & 87.11 & 87.58 & 15.14 & 0.46 & 15.56 & 17.92 & 3 \\
\hline Pump 2 & 6.206 & 7.35 & 177.1 & 177.9 & 32.12 & 0.79 & 32.91 & 18.54 & 2.41 \\
\hline Turbine & 8.39 & 10.73 & 2425 & 2436 & 665.2 & 11.57 & 675.7 & 27.9 & 1.71 \\
\hline $\begin{array}{l}\text { Expansion } \\
\text { valve }\end{array}$ & 4.49 & 4.73 & 229.1 & 229.1 & 12.11 & 0 & 12.11 & 5.28 & 0 \\
\hline
\end{tabular}

Table 27. The exergoenvironmental results of each component for R236FA.

\begin{tabular}{|c|c|c|c|c|c|c|c|c|c|}
\hline Component & $\begin{array}{c}b_{F} \\
(\mathrm{mpts} / \mathrm{MJ})\end{array}$ & $\begin{array}{c}b_{P} \\
(\mathrm{mpts} / \mathrm{MJ})\end{array}$ & $\begin{array}{c}\dot{B}_{F} \\
(\mathrm{mpts} / \mathrm{h})\end{array}$ & $\begin{array}{c}\dot{B}_{P} \\
(\mathrm{mpts} / \mathrm{h}\end{array}$ & $\begin{array}{c}\dot{B}_{D} \\
(\mathrm{mpts} / \mathrm{h})\end{array}$ & $\begin{array}{c}\dot{Y} \\
(\mathrm{mpts} / \mathrm{h})\end{array}$ & $\begin{array}{c}\dot{B}_{D}+\dot{Y} \\
(\mathrm{mpts} / \mathrm{h})\end{array}$ & $\begin{array}{c}r_{B} \\
(\%)\end{array}$ & $\begin{array}{l}f_{B} \\
(\%)\end{array}$ \\
\hline Condenser & 4.38 & 38.44 & 878.9 & 879 & 6826 & 0.06 & 6826.06 & 776.6 & 0.009 \\
\hline $\mathrm{CPC}$ & 0 & 2.29 & 0 & 1857 & 4291 & 1857 & 6148 & Infinity & 30.21 \\
\hline Ejector & 3.905 & 4.38 & 2083 & 2083 & 256.3 & 0 & 256.3 & 12.3 & 0 \\
\hline Evaporator & 4.721 & 12.82 & 71.39 & 73.06 & 120.86 & 1.66 & 122.3 & 171.6 & 1.35 \\
\hline HRVG & 2.444 & 4.5 & 2035 & 2178 & 1576 & 143.1 & 1719 & 84.4 & 8.32 \\
\hline Pump 1 & 6.206 & 7.32 & 78.95 & 79.38 & 13.83 & 0.42 & 14.25 & 18.06 & 2.97 \\
\hline Pump 2 & 6.206 & 7.35 & 177.1 & 177.9 & 32.12 & 0.79 & 32.91 & 18.57 & 2.41 \\
\hline Turbine & 5.997 & 7.67 & 1307 & 1317 & 355.6 & 9.43 & 365.1 & 27.92 & 2.58 \\
\hline $\begin{array}{l}\text { Expansion } \\
\text { valve }\end{array}$ & 4.386 & 4.72 & 120.4 & 120.4 & 9.22 & 0 & 9.22 & 7.65 & 0 \\
\hline
\end{tabular}

Table 28. The exergoenvironmental results of each component for R245fa.

\begin{tabular}{|c|c|c|c|c|c|c|c|c|c|}
\hline Component & $\begin{array}{c}b_{F} \\
(\mathrm{mpts} / \mathrm{MJ})\end{array}$ & $\begin{array}{c}b_{P} \\
(\mathrm{mpts} / \mathrm{MJ})\end{array}$ & $\begin{array}{c}\dot{B}_{F} \\
(\mathrm{mpts} / \mathrm{h})\end{array}$ & $\begin{array}{c}\dot{B}_{P} \\
\text { (mpts/h }\end{array}$ & $\begin{array}{c}\dot{B}_{D} \\
(\mathrm{mpts} / \mathrm{h})\end{array}$ & $\begin{array}{c}\dot{Y} \\
(\mathrm{mpts} / \mathrm{h})\end{array}$ & $\begin{array}{c}\dot{B}_{D}+\dot{Y} \\
(\mathrm{mpts} / \mathrm{h})\end{array}$ & $\begin{array}{c}r_{B} \\
(\%)\end{array}$ & $\begin{array}{l}f_{B} \\
(\%)\end{array}$ \\
\hline Condenser & 3.37 & 3.46 & 66.57 & 66.63 & 1.65 & 0.05 & 1.7 & 2.56 & 3.47 \\
\hline $\mathrm{CPC}$ & 0 & 2.28 & 0 & 2267 & 5197 & 2267 & 7464 & Infinity & 30.37 \\
\hline Ejector & 1.03 & 3.37 & 475.5 & 475.5 & 1075 & 0 & 1075 & 226.1 & 0 \\
\hline Evaporator & 3.88 & 9.09 & 79.96 & 82.01 & 105.1 & 2.05 & 107.15 & 134 & 1.91 \\
\hline HRVG & 2.4 & 3.78 & 2445 & 2615 & 1233 & 169.8 & 1402.8 & 57.37 & 12.1 \\
\hline Pump 1 & 6.206 & 7.33 & 92.72 & 93.22 & 16.39 & 0.49 & 16.9 & 18.21 & 2.94 \\
\hline Pump 2 & 6.206 & 7.35 & 177.1 & 177.9 & 32.12 & 0.79 & 32.91 & 18.57 & 2.4 \\
\hline Turbine & 7.47 & 9.6 & 2561 & 2574 & 715.7 & 13.07 & 729.4 & 28.4 & 1.79 \\
\hline $\begin{array}{c}\text { Expansion } \\
\text { valve }\end{array}$ & 3.37 & 3.88 & 40.89 & 40.89 & 6.18 & 0 & 6.8 & 15.13 & 0 \\
\hline
\end{tabular}

Table 29. The exergoenvironmental results of each component for R134a.

\begin{tabular}{|c|c|c|c|c|c|c|c|c|c|}
\hline Component & $\begin{array}{c}b_{F} \\
(\mathrm{mpts} / \mathrm{MJ})\end{array}$ & $\begin{array}{c}b_{P} \\
(\mathrm{mpts} / \mathrm{MJ})\end{array}$ & $\begin{array}{c}\dot{B}_{F} \\
(\mathrm{mpts} / \mathrm{h})\end{array}$ & $\begin{array}{c}\dot{B}_{P} \\
\text { (mpts/h }\end{array}$ & $\begin{array}{c}\dot{B}_{D} \\
(\mathrm{mpts} / \mathrm{h})\end{array}$ & $\begin{array}{c}\dot{Y} \\
(\mathrm{mpts} / \mathrm{h})\end{array}$ & $\begin{array}{c}\dot{B}_{D}+\dot{Y} \\
(\mathrm{mpts} / \mathrm{h})\end{array}$ & $\begin{array}{c}r_{B} \\
(\%)\end{array}$ & $\begin{array}{l}f_{B} \\
(\%)\end{array}$ \\
\hline Condenser & 6.88 & 39.08 & 597.11 & 597.17 & 2794 & 0.056 & 2794.1 & 468 & 0.002 \\
\hline $\mathrm{CPC}$ & 0 & 2.28 & 0 & 2205 & 5061 & 2205 & 7266 & Infinity & 30.35 \\
\hline Ejector & 6.414 & 6.88 & 5926 & 5926 & 430.5 & 0 & 0 & $7.26^{\circ}$ & 0 \\
\hline Evaporator & 7.176 & 17.47 & 133.9 & 135.9 & 190.3 & 1.92 & 192.2 & 143.4 & 1 \\
\hline HRVG & 2.411 & 6.88 & 2383 & 2549 & 4255 & 165.9 & 4420 & 185.4 & 3.75 \\
\hline Pump 1 & 6.206 & 7.29 & 41.61 & 41.7 & 7.2 & 0.13 & 7.33 & 17.62 & 1.8 \\
\hline Pump 2 & 6.206 & 7.35 & 177.1 & 177.9 & 32.12 & 0.79 & 32.91 & 18.57 & 2.4 \\
\hline Turbine & 9.08 & 11.56 & 1860 & 1869 & 499 & 9.03 & 508.1 & 27.3 & 1.77 \\
\hline $\begin{array}{c}\text { Expansion } \\
\text { valve }\end{array}$ & 6.88 & 7.17 & 532 & 532 & 22.9 & 0 & 0 & 4.3 & 0 \\
\hline
\end{tabular}

In order to select the best working fluids to use in the CCP cycle, the cycle should be checked in different terms. The priority for a thermodynamic cycle is the rates and impacts of the product that is consisted of working fluid processing. In this analysis, the outlet of the evaporator and the turbine are considered as the final product. These values can have direct effects on cost, efficiency, and environmental impacts. The most important proposal that 
can be considered is to make the maximum energy and exergy efficiencies in a way that it be possible to manage it economically. Therefore, it is tried to decrease the product cost rate and total cost rate in order to make it more economical.

One of the advantages of the presented research is the CCP cycle installs without fossil fuel combustion, and a lack of carbon dioxide release follows it. Moreover, the cycle's needed heat is provided by CPC. On the other hand, all component materials should be compatible with the environment.

In Table 30, the results of the analysis of the organic fluids have been compared. R152A and R245fa have the most rate of energy efficiency and exergy efficiency, among other fluids. However, in terms of economy, R245fa fluid is favorable because, with the same efficiency, it has a lower total cost and product cost rates compared to R152A. On the other hand, R134a has the lowest energy efficiency, exergy efficiency, and R236FA has the lowest product cost rate among all working fluids. In addition, R245fa, with the lowest value of the environmental impact rate, is the best choice environmentally while R152A has the most value of environmental impact rate.

\subsection{Sensitivity Analysis}

\subsubsection{The effects of the turbine inlet temperature}

The effects of turbine inlet temperature on energy efficiency, exergy efficiency, product cost rate, and total cost rate have been checked. The range of its variations is from $374(\mathrm{~K})$ to $392(\mathrm{~K})$. According to Figure 5 and Figure 6 , by increasing $T_{2}$, the energy efficiency and exergy efficiency of all five fluids will decrease, and the R236FA and R134a have the most energy efficiency decrease by about $6 \%$. It can be concluded that by increasing $\mathrm{T}_{2}$, the exergy destruction rate will increase.

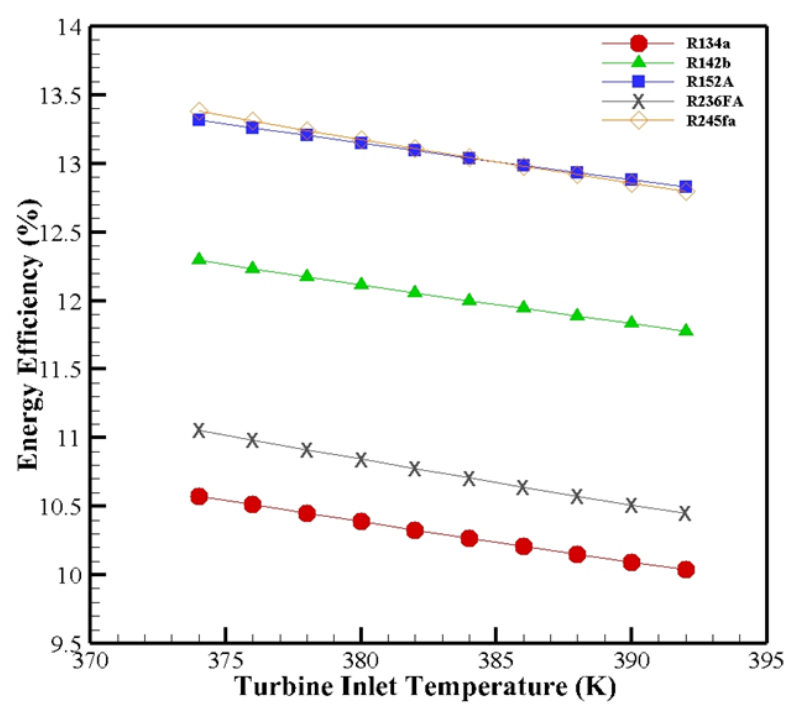

Figure 5. The effects of the turbine inlet temperature on energy efficiency.

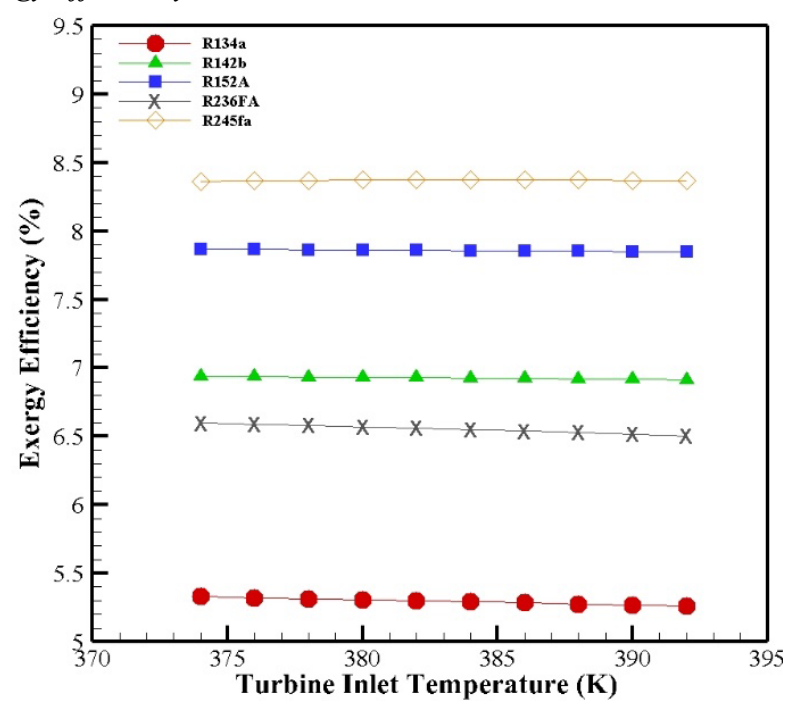

Figure 6. The effects of the turbine inlet temperature on the exergy efficiency.

The cost function analysis indicates that by increasing $\mathrm{T}_{2}$, the rates of total cost and the product cost will increase, and the product cost of R236FA has the most increase about $23 \%$, and total cost of R152A has the most growth about10\%(Figure 7 and Figure 8). This incremental process is an unfavorable factor in the cycle. The results of changes in turbine inlet temperature indicate that lower $\mathrm{T}_{2}$ is more appropriate for the operation cycle.

Table 30. Comparison of different working fluids performance.

\begin{tabular}{ccccccc}
\hline Fluid & $\begin{array}{c}\text { Energy } \\
\text { efficiency } \\
(\%)\end{array}$ & $\begin{array}{c}\text { Exergy } \\
\text { efficiency } \\
(\%)\end{array}$ & $\begin{array}{c}\text { Cooling } \\
\text { capacity } \\
(\mathrm{kW})\end{array}$ & $\begin{array}{c}\text { Product cost rate } \\
(\$ / \mathrm{h})\end{array}$ & $\begin{array}{c}\text { Total cost rate } \\
(\$ / \mathrm{h})\end{array}$ & $\begin{array}{c}\text { Environmental } \\
\text { impact rate }\end{array}$ \\
\hline R152A & 12.9 & 7.8 & 128.2 & 46.2 & 266.5 & 22688 \\
R142b & 11.8 & 6.9 & 92.05 & 34.1 & 148 & 12576 \\
R236FA & 10.5 & 6.5 & 64.8 & 20.6 & 175.5 & 15493 \\
R245fa & 12.9 & 8.3 & 88.225 & 36 & 128.4 & 10836 \\
R134a & 10.1 & 5.2 & 80.025 & 27 & 177.6 & 15220 \\
\hline
\end{tabular}




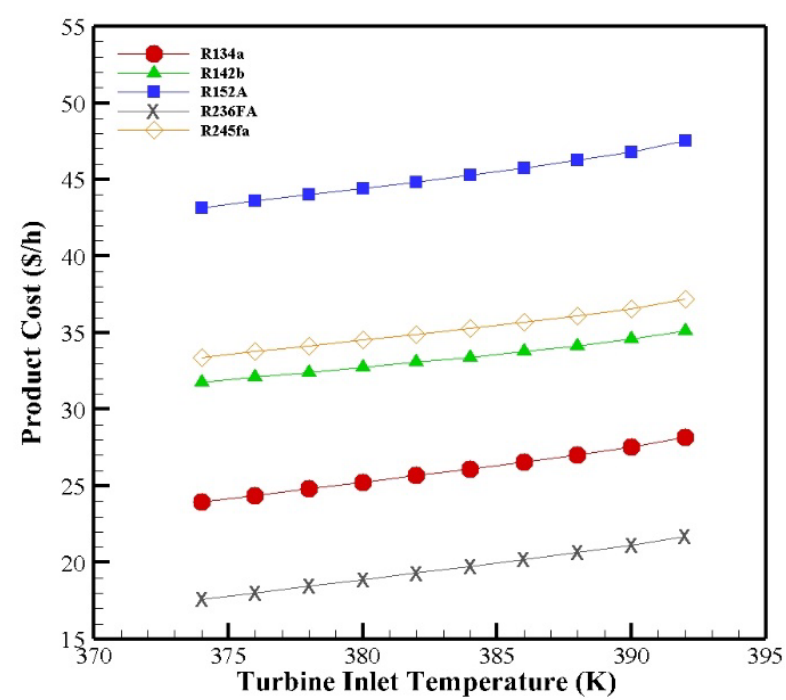

Figure 7. The effects of the turbine inlet temperature on the product cost rate.

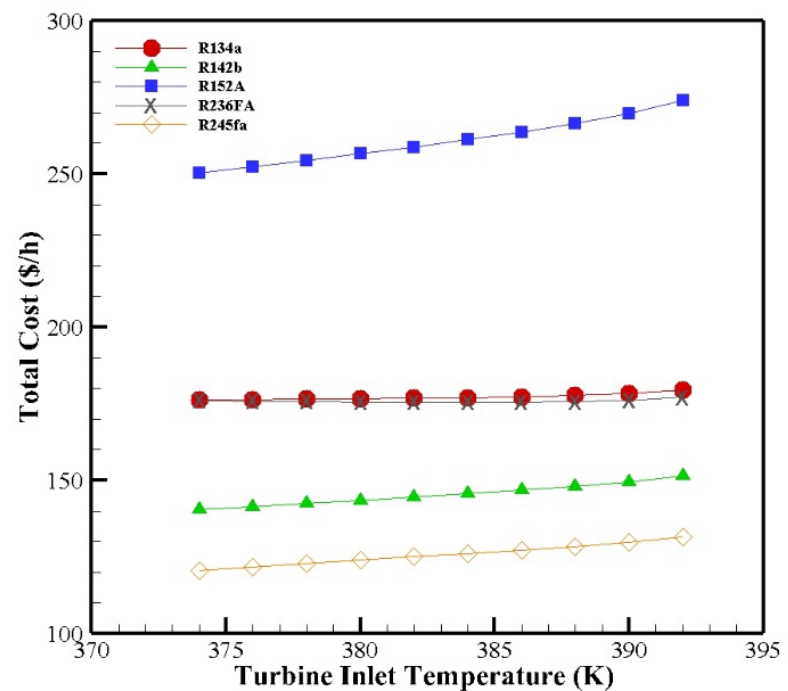

Figure 8. The effects of the turbine inlet temperature on the total cost rate.

\subsubsection{The effects of the turbine inlet pressure}

The results of changes in the turbine inlet pressure are shown in Figs.9 to 12. The range of pressure changes is considered $1(\mathrm{MPa})$ to $1.7(\mathrm{MPa})$. Because the generated power in the turbine is related to its pressure difference created before and after it and its effects on cycle product, $\mathrm{P}_{3}$ changes analysis is more important than the other parameters. The results indicate that energy efficiency and exergy efficiency increase by increasing $\mathrm{P}_{3}$. R134a has the most energy efficiency and exergy efficiency increase by $40 \%$. Increasing in $\mathrm{P}_{3}$ is the most significant factor in decreasing the exergy destruction rate.

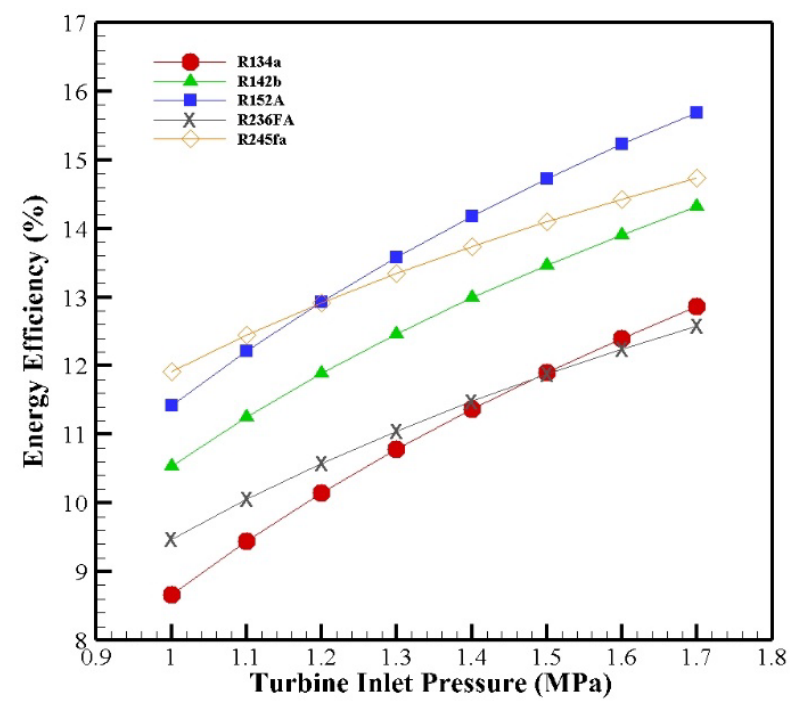

Figure 9. The Effects of the turbine inlet pressure on energy efficiency.

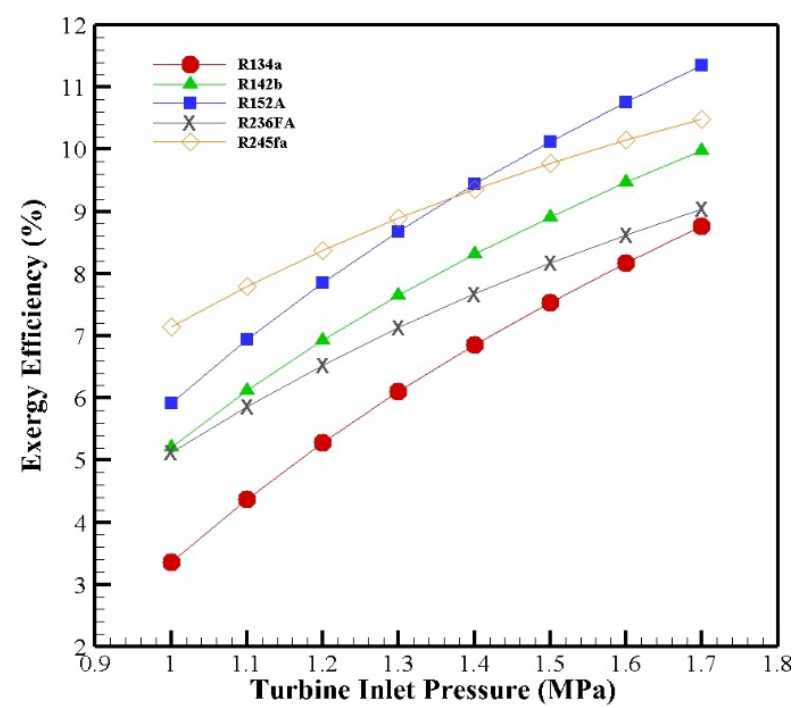

Figure 10. The Effects of the turbine inlet pressure on the exergy efficiency.

According to Figure 11, by increasing $\mathrm{P}_{3}$, the product cost rate in all the analyzed fluids will increase partially. Because the exergy efficiency increased, it shows that the CCP cycle with larger $\mathrm{P}_{3}$ has more capacity, but according to Figure 12, it is decreased because of the decrease of exergy destruction cost rate. 


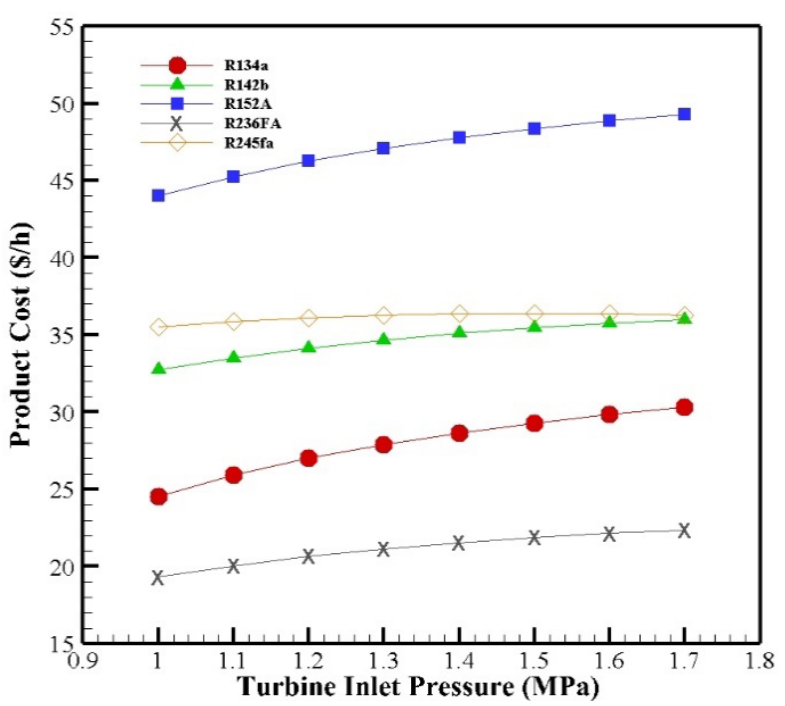

Figure 11. The Effects of the turbine inlet pressure on the product cost rate.

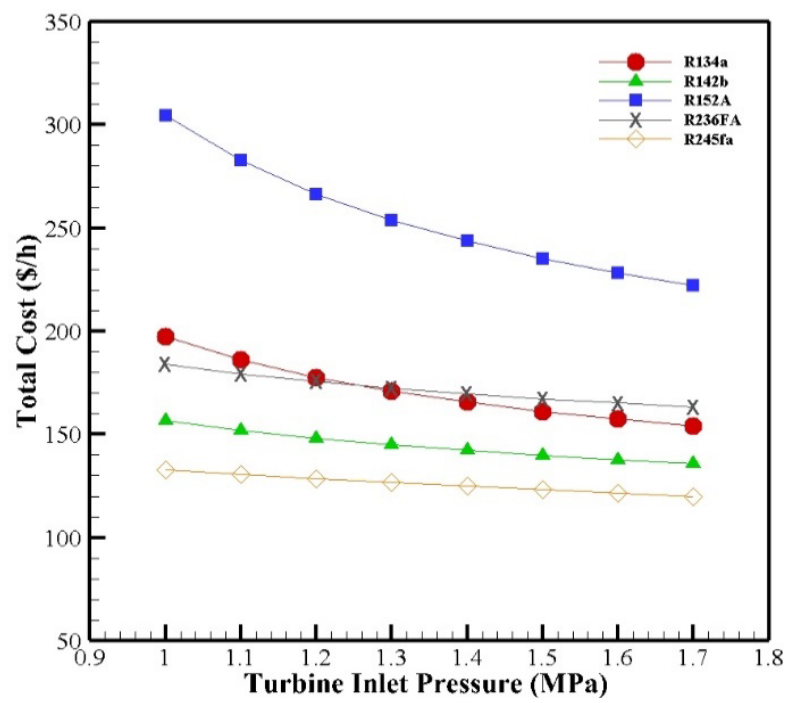

Figure 12. The Effects of the turbine inlet pressure on the total cost rate.

\subsection{Optimization Results}

In this study, multi-objective optimization is done by using NSGA II to find an appropriate condition. Therefore, objective functions are determined through this process. The Pareto frontier diagram indicates the results of the optimization. Three essential variables with a specific and same changes range are used according to Table 31 . Because one of the most important suggestions of this research is comparing the working fluids, the results are indicated on a diagram for a better description. In most thermodynamic cycles, increasing efficiency will increase cost, which is an unfavorable factor. The optimization principles are based on maximizing energy and exergy efficiencies, while product cost and product environmental impact rates should be minimized.

An ideal point on the Pareto frontier is when each objective function is optimized regardless of satisfaction with the other objective functions. Obviously, in multiobjective optimization, each objective function cannot have each objective function in its optimal condition acquired a single-objective optimization. Thus, the ideal point is not located on the Pareto frontier. In the LINMAP method, the solution with a minimum distance from the ideal point is selected as the final optimal solution. In this study, the LINMAP method has been used to determine the optimal point in multi-objective optimizations.

Table 31. Decision variable boundaries for the optimal.

\begin{tabular}{cc}
\hline Decision variables & Feasibility values \\
\hline Turbine inlet pressure $(\mathrm{kPa})$ & $1000 \leq \mathrm{P}_{2} \leq 1700$ \\
Turbine inlet Temperature $(\mathrm{K})$ & $374 \leq \mathrm{T}_{2} \leq 392$ \\
Turbine inlet mass flow rate $(\mathrm{kg} / \mathrm{s})$ & $4.4 \leq \dot{m}_{2} \leq 5.1$ \\
\hline
\end{tabular}

According to Figure13, the optimization results with objective functions of exergy efficiency and total product cost rate for discussed fluids are shown. Point E indicates the optimal condition of R152A that has higher exergy efficiency and total product cost compared to other fluids. However, when comparing it to other fluids, it is shown that the almost same exergy efficiency in lower total product cost rate can be acquired like $\mathrm{C}$ and $\mathrm{D}$ points that are related to $\mathrm{R} 142 \mathrm{~b}$ and $\mathrm{R} 245 \mathrm{fa}$. At point $\mathrm{A}$, the total product cost is about 60 percent lower than at point $\mathrm{E}$, while its exergy efficiency is just 17 percent lower. Therefore, it can be concluded that R234FA is the optimal choice in terms of exergy and exergoeconomic analyses. Choosing the appropriate working fluids for optimal operation conditions significantly impacts the outlet cycle's product quality.

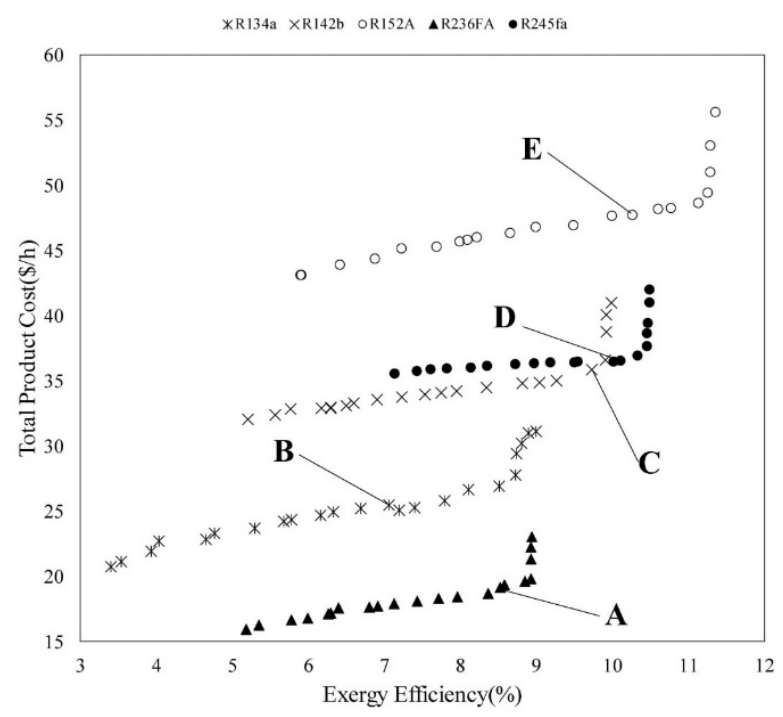

Figure 13. The Pareto frontier of the optimum solution with the exergy efficiency and product cost rate.

According to Figure 14, the optimization results with energy efficiency and product environmental impact objective functions are shown. Among discussed fluids in this study, point I related to $\mathrm{R} 245 \mathrm{fa}$ has the most efficiency while product environmental impact has an average rate. Furthermore, point $\mathrm{H}$ shows that the rates of $\mathrm{R} 142 \mathrm{~b}$ are in the next place. On the other hand, point F, which indicates that R236FA has the lowest environmental impact. 
Table 32. Optimized values of different design parameters.

\begin{tabular}{|c|c|c|c|c|c|c|}
\hline Parameters & The base case of 744 & The base case of $744 \mathrm{~A}$ & $\bar{B}$ & $\bar{E}$ & $\overline{\mathrm{H}}$ & $\bar{K}$ \\
\hline Compressor outlet pressure(MPa) & 9.75 & 9.75 & 9.59 & 9.60 & 9.85 & 9.64 \\
\hline Ejector inlet Temperature $(\mathrm{K})$ & 313 & 313 & 315.1 & 315.8 & 316.1 & 316.8 \\
\hline Evaporator outlet temperature $(\mathrm{K})$ & 278 & 278 & 277.4 & 277.9 & 278 & 278 \\
\hline Exergy efficiency $(\%)$ & 30.74 & 35.98 & 28.51 & 34.44 & - & - \\
\hline Total product $\operatorname{cost}(\$ / \mathrm{h})$ & 1.56 & 1.96 & 1.44 & 1.85 & - & - \\
\hline Coefficient of operation & 2.82 & 2.73 & - & - & 2.67 & 2.76 \\
\hline Product environment impact(mpts/h) & 154.03 & 204.25 & - & - & 149.01 & 200.482 \\
\hline
\end{tabular}

The parameters and value of objective functions from multi-objective optimization are shown in Table 32. Therefore, to make the cycle's optimal condition, this table's presented values should be used.

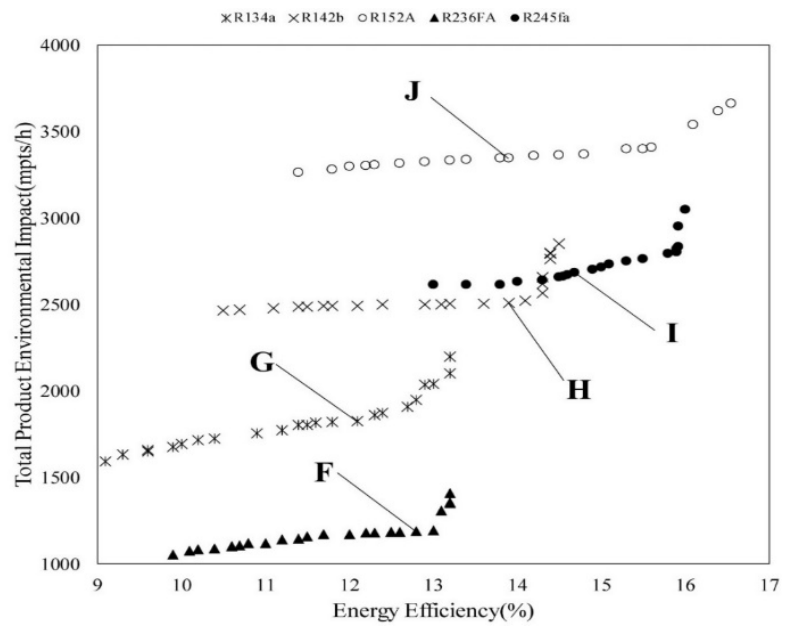

Figure 14. The Pareto frontier of the optimum solution with energy efficiency and product environmental impact.

\section{Conclusion}

The analyzed cycle consists of two parts include the CCP cycle and the solar system. Because of the high capacity of the compound, a parabolic collector (CPC) is used. The operation of the CCP cycle with different working fluids is compared and checked. Because each of the fluids has different thermodynamic properties, the solar cycle's needed heat is different for all of them. The obtained number of collectors is different for each of the fluids. R152A has the largest number of collectors, and R236FA has the lowest number of collectors.

On the other hand, the number of collectors used in the cycle directly relates to the total cost. All the input parameters except turbine outlet pressure are considered the same with all fluids. The proposed cycle is checked in terms of energy, exergy, exergoeconomic, and exergoenvironmental. In the end, multi-objective optimization is done by using different objective functions.

- The energy analysis results show that among checked fluids, the most energy efficiency is related to R152A and R245fa by $12.9 \%$, the lowest value is associated with R134a by $10.1 \%$.
At the same time, R152A provides the most outlet power for the turbine.

- The survey on irreversibility indicates that CPC and HRVG have the highest value of exergy destruction rate.

- According to the analysis by using the second thermodynamic law, the most exergy efficiency is for R245fa by $8.3 \%$, and the lowest value is for R134a by $5.2 \%$.

- The exergoeconomic analysis results and calculating the product cost rate and total cost rate indicate that their most rate is related to R152A while R236FA presents the economical product.

- According to the obtained results from exergoenvironmental analysis with checking different working fluids, it is determined that R152A and R245fa have the highest and lowest value of environmental impact rate, respectively.

- By checking and comparing the different working fluids, it can be concluded that R245fa, while having the most efficiency of energy and exergy, has the lowest total cost and environmental impact rate. Therefore, R245fa is the most appropriate fluid for the CCP cycle from different viewpoints.

- The sensitivity analysis results with changes of the turbine inlet pressure indicate that its increase makes the efficiency of energy and exergy higher while decreasing the total cost rate of all fluids, and it is considered as a favorable factor.

The diagram of optimization results indicates that points D and I are the most appropriate among all of the obtained points for different fluids related to R245fa.

\section{Nomenclature}

$\begin{array}{cc}\mathrm{A} & \text { Heat transfer area }\left(\mathrm{m}^{2}\right) \\ \mathrm{b} & \text { Unit environmental impact }(\mathrm{mpts} / \mathrm{MJ}) \\ \dot{\mathrm{B}} & \text { Environmental impact rate }(\mathrm{mpts} / \mathrm{h}) \\ \dot{\mathrm{B}}_{\mathrm{D}} & \text { Destruction environmental impact rate } \\ & (\mathrm{mpts} / \mathrm{h}) \\ \mathrm{c} & \text { The unit cost of exergy }(\$ / \mathrm{MJ}) \\ \dot{\mathrm{C}} & \text { Cost rate }(\$ / \text { hour }) \\ \dot{\mathrm{C}}_{\mathrm{D}} & \text { Destruction cost rate }(\$ / \text { hour })\end{array}$




$\mathrm{c}_{\mathrm{p}}$
$\dot{\mathrm{C}}_{\mathrm{P}}$
$\dot{\mathrm{C}}_{\text {total }}$
$\mathrm{CCHP}$
$\mathrm{CCP}$
$\mathrm{CPC}$
$\mathrm{CRF}$
$\dot{\mathrm{E}}$
$\mathrm{ETC}$
$\mathrm{EX}$
$\mathrm{f}_{\mathrm{b}}$
$\mathrm{f}_{\mathrm{c}}$
$\mathrm{FPC}$
$\mathrm{h}$
$\mathrm{HRVG}$
$\mathrm{L}$
$\mathrm{LCA}$
$\dot{\mathrm{m}}$
$\mathrm{n}$
$\mathrm{OFC}$
$\mathrm{ORC}$
$\mathrm{P}$
$\mathrm{r}_{\mathrm{b}}$
$\mathrm{r}_{\mathrm{c}}$
$\mathrm{s}$
$\mathrm{t}$
$\mathrm{T}$
$\mathrm{U}$
$\mathrm{U}_{\mathrm{L}}$
$\mathrm{V}$
$\mathrm{w}$
$\dot{\mathrm{W}}$

Specific heat $(\mathrm{kJ} / \mathrm{kg} \mathrm{K})$

Production cost rate (\$/hour)

Total cost rate ( $\$ /$ hour)

Combined cooling, heating, and power

Combine cooling and power

Compound parabolic collector

Capital recovery factor

Energy rate $(\mathrm{kW})$

Evacuated tube collector

Exergy rate $(\mathrm{kW})$

Exergoenvironmental factor

Exergoeconomic factor

Flat plate collector

Specific enthalpy $(\mathrm{kJ} / \mathrm{kg})$

Heat recovery vapor generator Loss

Life cycle assessment

Mass flow rate $(\mathrm{kg} / \mathrm{s})$

Component lifetime (year)

Organic flash cycle

Organic Rankine cycle Pressure (kPa)

Relative environmental impacts difference

Relative cost difference (\%)

Specific entropy $(\mathrm{kJ} / \mathrm{kg} \mathrm{K})$ Time (h)

Temperature (K)

Heat transfer coefficient $\left(\mathrm{W} / \mathrm{m}^{2} \mathrm{~K}\right)$

Collector heat loss coefficient $\left(\mathrm{W} / \mathrm{m}^{2} \mathrm{~K}\right)$

$\operatorname{Velocity}(\mathrm{m} / \mathrm{s})$

Weight(Ton)

Power(kw)
Component-related environmental impacts $(\mathrm{mPts} / \mathrm{h})$

capital investment cost rate (\$/hour)

Investment $\operatorname{cost}(\$ /$ hour $)$

\section{Greek Letters}

absorptivity of receiver

correction factor for diffuse radiation

Exergy destruction ratio

Efficiency

Entrainment ratio

Mirror reflectivity

Rupture stress(MPa)/ Stefan-Boltzmann constant $\left(\mathrm{J} \cdot \mathrm{m}^{-2} \cdot \mathrm{s}^{-1} \cdot \mathrm{K}^{-4}\right)$

transmissivity of the cover glazing

effective transmissivity of CPC

Maintenance factor

\section{Subscripts and Superscripts}

Dead state

Ambient

Chemical

Destruction

Output

Fluid

Fuel

Input

Product

Physical

\section{References}

[1] A. Khaliq, "Energetic and exergetic performance investigation of a solar based integrated system for cogeneration of power and cooling," Applied Thermal Engineering, vol. 112, pp. 1305-1316, 2017.

[2] M. Berković-Šubić, M. Rauch, D. Dović, and M. Andrassy, "Primary energy consumption of the dwelling with solar hot water system and biomass boiler," Energy conversion and management, vol. 87, pp. 1151-1161, 2014.

[3] J. Qin, E. Hu, and X. Li, "Solar aided power generation: A review," Energy and Built Environment, vol. 1, no. 1, pp. 11-26, 2020.

[4] E. Bellos, D. Korres, C. Tzivanidis, and K. Antonopoulos, "Design, simulation and optimization of a compound parabolic collector," Sustainable Energy Technologies and Assessments, vol. 16, pp. 53-63, 2016.

[5] F. Khalid, I. Dincer, and M. A. Rosen, "Thermoeconomic analysis of a solar-biomass integrated multigeneration system for a community," Applied Thermal Engineering, vol. 120, pp. 645-653, 2017.

[6] M. Mehrpooya, M. Ashouri, and A. Mohammadi, "Thermoeconomic analysis and optimization of a regenerative two-stage organic Rankine cycle coupled with liquefied natural gas and solar energy," Energy, vol. 126, pp. 899-914, 2017.

A. Moharramian, S. Soltani, M. A. Rosen, S. Mahmoudi, and M. Jafari, "Conventional and enhanced thermodynamic and exergoeconomic analyses of a photovoltaic combined cycle with biomass post firing and hydrogen production," Applied Thermal Engineering, vol. 160, p. 113996, 2019.

[8] A. Behzadi, E. Gholamian, P. Ahmadi, A. Habibollahzade, and M. Ashjaee, "Energy, exergy and exergoeconomic (3E) analyses and multi-objective optimization of a solar and geothermal based integrated energy system," Applied Thermal Engineering, vol. 143, pp. 1011-1022, 2018.

[9] F. A. Boyaghchi and P. Heidarnejad, "Thermoeconomic assessment and multi objective optimization of a solar micro CCHP based on Organic Rankine Cycle for domestic application," Energy conversion and Management, vol. 97, pp. 224-234, 2015.

[10] T. Sokhansefat, A. Kasaeian, K. Rahmani, A. H. Heidari, F. Aghakhani, and O. Mahian, "Thermoeconomic and environmental analysis of solar flat plate and evacuated tube collectors in cold climatic conditions," Renewable Energy, vol. 115, pp. 501-508, 2018.

[11] S. Salehi, M. Yari, and M. Rosen, "Exergoeconomic comparison of solar-assisted absorption heat pumps, solar heaters and gas 
boiler systems for district heating in Sarein Town, Iran," Applied Thermal Engineering, vol. 153, pp. 409-425, 2019.

[12] M. Sadi and A. Arabkoohsar, "Exergoeconomic analysis of a combined solar-waste driven power plant," Renewable energy, vol. 141, pp. 883-893, 2019.

[13] J. Wellmann, B. Meyer-Kahlen, and T. Morosuk, "Exergoeconomic evaluation of a CSP plant in combination with a desalination unit," Renewable Energy, vol. 128, pp. 586-602, 2018.

[14] R. Panahi, M. H. Khanjanpour, A. A. Javadi, M. Akrami, M. Rahnama, and M. Ameri, "Analysis of the thermal efficiency of a compound parabolic Integrated Collector Storage solar water heater in Kerman, Iran," Sustainable Energy Technologies and Assessments, vol. 36, p. 100564, 2019.

[15] A. Rosato, A. Ciervo, G. Ciampi, M. Scorpio, F. Guarino, and S. Sibilio, "Energy, Environmental and Economic Dynamic Assessment of a Solar Hybrid Heating Network Operating with a Seasonal Thermal Energy Storage Serving an Italian Small-Scale Residential District: Influence of Solar and Back-up Technologies," Thermal Science and Engineering Progress, p. $100591,2020$.

[16] H. V. Modabber and M. K. Manesh, "4E dynamic analysis of a water-power cogeneration plant integrated with solar parabolic trough collector and absorption chiller," Thermal Science and Engineering Progress, vol. 21, p. 100785.

[17] A. Baghernejad, M. Yaghoubi, and K. Jafarpur, "Exergoeconomic optimization and environmental analysis of a novel solartrigeneration system for heating, cooling and power production purpose," Solar Energy, vol. 134, pp. 165-179, 2016.

[18] S. Saadon, L. Gaillard, C. Menezo, and S. Giroux-Julien, "Exergy, exergoeconomic and enviroeconomic analysis of a building integrated semi-transparent photovoltaic/thermal (BISTPV/T) by natural ventilation," Renewable Energy, vol. 150, pp. 981-989, 2020.

[19] H. Caliskan, "Energy, exergy, environmental, enviroeconomic, exergoenvironmental (EXEN) and exergoenviroeconomic (EXENEC) analyses of solar collectors," Renewable and Sustainable Energy Reviews, vol. 69, pp. 488-492, 2017.

[20] H. Montazerinejad, P. Ahmadi, and Z. Montazerinejad, "Advanced exergy, exergoeconomic and exrgo-environmental analyses of a solar based trigeneration energy system," Applied Thermal Engineering, vol. 152, pp. 666685, 2019.

[21] M. Esmaeilzadehazimi, M. H. K. Manesh, B. B. Heleyleh, and H. V. Modabbaer, "4E Analysis of Integrated MHD-Combined Cycle," International Journal of Thermodynamics, vol. 22, no. 4, pp. 219-228, 2019.

[22] G. Bonforte, J. Buchgeister, G. Manfrida, and K. Petela, "Exergoeconomic and exergoenvironmental analysis of an integrated solar gas turbine/combined cycle power plant," Energy, vol. 156, pp. 352-359, 2018.

[23] E. J. Cavalcanti, M. S. Lima, and G. F. de Souza, "Comparison of carbon capture system and concentrated solar power in natural gas combined cycle: Exergetic and exergoenvironmental analyses," Renewable Energy, 2019.

[24] S. Sanaye, M. Amani, and P. Amani, "4E modeling and multi-criteria optimization of CCHPW gas turbine plant with inlet air cooling and steam injection," Sustainable Energy Technologies and Assessments, vol. 29, pp. 70$81,2018$.

[25] K. G. Mofrad, S. Zandi, G. Salehi, and M. H. K. Manesh, "4E Analyses and Multi-Objective Optimization of Cascade Refrigeration Cycles with Heat Recovery System," Thermal Science and Engineering Progress, p. 100613, 2020.

[26] K. G. Mofrad, S. Zandi, G. Salehi, and M. K. Manesh, "Comparative 4E and advanced exergy analyses and multi-objective optimization of refrigeration cycles with a heat recovery system," International Journal of Thermodynamics (IJoT), vol. 23, no. 3, pp. 197214, 2020.

[27] S. Adibhatla and S. Kaushik, "Energy, exergy, economic and environmental (4E) analyses of a conceptual solar aided coal fired $500 \mathrm{MWe}$ thermal power plant with thermal energy storage option," Sustainable Energy Technologies and Assessments, vol. 21, pp. 89-99, 2017.

[28] M. Ameri and M. Mohammadzadeh, "Thermodynamic, thermoeconomic and life cycle assessment of a novel integrated solar combined cycle (ISCC) power plant," Sustainable Energy Technologies and Assessments, vol. 27, pp. 192-205, 2018.

[29] F. A. Ghaith, "Performance of solar powered cooling system using Parabolic Trough Collector in UAE," Sustainable Energy Technologies and Assessments, vol. 23, pp. 21-32, 2017.

[30] E. Rafat, M. Babaelahi, and E. Mofidipour, "Sustainability analysis of low temperature solar-driven kalina power plant using emergy concept," International Journal of Thermodynamics, vol. 22, no. 3, pp. 118-126, 2019.

[31] H. V. MODABBER and M. H. K. MANESH, "4E Analysis of Power and Water Cogeneration Plant based on Integrated MED-TVC and RO Desalination Units," International Journal of Thermodynamics, vol. 23, no. 2, pp. 107-126.

[32] F. A. Boyaghchi, M. Chavoshi, and V. Sabeti, "Optimization of a novel combined cooling, heating and power cycle driven by geothermal and solar energies using the water/CuO (copper oxide) nanofluid," Energy, vol. 91, pp. 685-699, 2015.

[33] F. A. Boyaghchi and M. Chavoshi, "Multicriteria optimization of a micro solar-geothermal $\mathrm{CCHP}$ system applying water/ $\mathrm{CuO}$ nanofluid based on exergy, exergoeconomic and exergoenvironmental concepts," Applied 
Thermal Engineering, vol. 112, pp. 660-675, 2017.

[34] A. Nemati, H. Nami, and M. Yari, "Assessment of different configurations of solar energy driven organic flash cycles (OFCs) via exergy and exergoeconomic methodologies," Renewable Energy, vol. 115, pp. 1231-1248, 2018.

[35] N. B. Desai and S. Bandyopadhyay, "Thermoeconomic comparisons between solar steam Rankine and organic Rankine cycles," Applied Thermal Engineering, vol. 105, pp. 862-875, 2016.

[36] "NIST National Institute of Standards and Technology, Thermophysical properties of fluid systems." USA. https://webbook.nist.gov/chemistry/fluid/ (accessed 2016).

[37] S. A. Kalogirou, Solar energy engineering: processes and systems. Academic Press, 2013.

[38] Y. A. Cengel and M. A. Boles, "Thermodynamics, An Engineering Approach, McGraw Hill," Higher education, 2007.

[39] "Processing, archiving and distributing Earth science data at the NASA Langley Research Center." https://eosweb.larc.nasa.gov/ (accessed 2020).

[40] R. Petela, "Exergy analysis of the solar cylindrical-parabolic cooker," Solar energy, vol. 79, no. 3, pp. 221-233, 2005.

[41] M. Colakoglu and A. Durmayaz, "Energy, exergy and environmental-based design and multiobjective optimization of a novel solardriven multi-generation system," Energy Conversion and Management, vol. 227, p. $113603,2021$.

[42] D. Y. Goswami, The CRC handbook of mechanical engineering. CRC press, 2004.

[43] J. Wang, Y. Dai, and Z. Sun, "A theoretical study on a novel combined power and ejector refrigeration cycle," International Journal of Refrigeration, vol. 32, pp. 1186-1194, 2009.

[44] A. Bejan, G. Tsatsaronis, and M. Moran, "Thermal Design and Optimization John Wiley and Sons," Inc. New York, 1996.

[45] S. Zandi, K. G. Mofrad, G. Salehi, M. H. K. Manesh, and A. Fazeli, "Multi-objective optimization and thermoeconomic analysis of a novel CCHP with TES and hybrid cooling for residential complex," Thermal Science and Engineering Progress, vol. 19, p. 100656, 2020.

[46] T. Parikhani, H. Azariyan, R. Behrad, H. Ghaebi, and J. Jannatkhah, "Thermodynamic and thermoeconomic analysis of a novel ammoniawater mixture combined cooling, heating, and power (CCHP) cycle," Renewable Energy, vol. 145, pp. 1158-1175, 2020.

[47] F. Mohammadkhani, N. Shokati, S. Mahmoudi, M. Yari, and M. Rosen, "Exergoeconomic assessment and parametric study of a Gas Turbine-Modular Helium Reactor combined with two Organic Rankine Cycles," Energy, vol. 65, pp. 533-543, 2014.

[48] A. Mosaffa, L. G. Farshi, C. I. Ferreira, and M. Rosen, "Exergoeconomic and environmental analyses of $\mathrm{CO} 2 / \mathrm{NH} 3$ cascade refrigeration systems equipped with different types of flash tank intercoolers," Energy Conversion and Management, vol. 117, pp. 442-453, 2016.

[49] X. Zhang, R. Zeng, K. Mu, X. Liu, X. Sun, and $\mathrm{H}$. Li, "Exergetic and exergoeconomic evaluation of co-firing biomass gas with natural gas in CCHP system integrated with ground source heat pump," Energy conversion and management, vol. 180, pp. 622-640, 2019.

[50] A. Khosravi, R. Koury, and L. Machado, "Thermo-economic analysis and sizing of the components of an ejector expansion refrigeration system," International Journal of Refrigeration, vol. 86, pp. 463-479, 2018.

[51] C. Zhou, E. Doroodchi, and B. Moghtaderi, "An in-depth assessment of hybrid solar-geothermal power generation," Energy conversion and management, vol. 74, pp. 88-101, 2013.

P. Ahmadi, I. Dincer, and M. A. Rosen, "Exergy, exergoeconomic and environmental analyses and evolutionary algorithm based multiobjective optimization of combined cycle power plants," Energy, vol. 36, pp. 5886-5898, 2011.

[53] E. J. C. Cavalcanti, "Exergoeconomic and exergoenvironmental analyses of an integrated solar combined cycle system," Renewable and Sustainable Energy Reviews, vol. 67, pp. 507519, 2017.

[54] L. Meyer, G. Tsatsaronis, J. Buchgeister, and L. Schebek, "Exergoenvironmental analysis for evaluation of the environmental impact of energy conversion systems," Energy, vol. 34, pp. 75-89, 2009.

[55] M. K. Manesh et al., "Exergoeconomic and exergoenvironmental evaluation of the coupling of a gas fired steam power plant with a total site utility system," Energy Conversion and Management, vol. 77, pp. 469-483, 2014. 